\title{
Phyto-Carbazole Alkaloids from the Rutaceae Family as Potential Protective Agents against Neurodegenerative Diseases
}

\author{
Mario A. Tan ${ }^{1}$, Niti Sharma ${ }^{2, *}$ and Seong Soo A. An ${ }^{2, *}$ (D) \\ 1 College of Science and Research Center for the Natural and Applied Sciences, University of Santo Tomas, \\ Manila 1015, Philippines; matan@ust.edu.ph \\ 2 Department of Bionano Technology, Gachon University, 1342 Seongnam-daero, Sujeong-Gu, \\ Seongnam 461-701, Korea \\ * Correspondence: nitisharma@gachon.ac.kr (N.S.); seongaan@gachon.ac.kr (S.S.A.A.); \\ Tel.: +82-31-750-8591 (N.S.); +82-31-750-8755 (S.S.A.A.)
}

Citation: Tan, M.A.; Sharma, N.; An, S.S.A. Phyto-Carbazole Alkaloids from the Rutaceae Family as Potential Protective Agents against Neurodegenerative Diseases.

Antioxidants 2022, 11, 493. https://doi.org/10.3390/ antiox11030493

Academic Editor: John T. Weber

Received: 18 January 2022

Accepted: 22 February 2022

Published: 1 March 2022

Publisher's Note: MDPI stays neutral with regard to jurisdictional claims in published maps and institutional affiliations.

Copyright: (C) 2022 by the authors. Licensee MDPI, Basel, Switzerland. This article is an open access article distributed under the terms and conditions of the Creative Commons Attribution (CC BY) license (https:// creativecommons.org/licenses/by/ $4.0 /)$.

\begin{abstract}
Plant-derived (phyto) carbazole alkaloids are an important class of compounds, presented in the family of Rutaceae (Genera Murraya, Clausena, Glycosmis, Micromelum and Zanthoxylum). Due to several significant biological activities, such as antitumor, antibacterial, antiviral, antidiabetic, antiHIV and neuroprotective activities of the parent skeleton (3-methylcarbazole), carbazole alkaloids are recognized as an important class of potential therapeutic agents. Neurodegenerative diseases (NDs) may exhibit a vast range of conditions, affecting neurons primarily and leading ultimately to the progressive losses of normal motor and cognitive functions. The main pathophysiological indicators of NDs comprise increasing atypical protein folding, oxidative stresses, mitochondrial dysfunctions, deranged neurotransmissions and neuronal losses. Phyto-carbazole alkaloids can be investigated for exerting multitarget approaches to ameliorating NDs. This review presents a comprehensive evaluation of the available scientific literature on the neuroprotective mechanisms of phyto-carbazole alkaloids from the Rutaceae family in ameliorating NDs.
\end{abstract}

Keywords: neurodegenerative disease; Rutaceae; phyto carbazole alkaloid; oxidative stress; neuroinflammation; Alzheimer's disease

\section{Introduction}

Neurodegenerative diseases (NDs) belong to a heterogeneous groups of disorders (Alzheimer's, Parkinson's, multiple sclerosis, amyotrophic lateral sclerosis, Huntington's disease, etc.), which could result in progressive loss of structure or function of the neurons. These neurological changes in the brain could lead to logical and/or functional deterioration over time. The main physiological indicators of NDs comprise increasing atypical protein misfolding, oxidative stress, mitochondrial dysfunction, deranged neurotransmission and neuronal loss [1,2].

Alzheimer's disease (AD) is the most prevalent form of ND and is described by declining cognitive and motor functions. Currently, the available drugs for the treatment of $\mathrm{AD}$ are acetyl cholinesterase (AChE) inhibitors (donepezil, galantamine and rivastigmine) or blockers of glutamate receptors (memantine). Recently, the Food and Drug Administration (FDA) approved an antibody drug (Aduhelm), which may improve AD symptoms. Yet, all these allopathy drugs have associated side effects, ranging from minor headache to swelling and brain haemorrhaging [3]. In this regard, plants could provide an effective and safer source of bioactive compounds to be used as a drug. Researchers have identified several plants with neuroprotective properties, like AChE inhibition, retarding atypical aggregation and scavenging free radicles, which protect against oxidative stress [3-5]. Additionally, several bioactive compounds have anti-inflammatory properties and reduce the activity of pro-inflammatory markers (interleukins (IL-6, IL-1 $\beta$ ), nitric oxide (NO), tumor 
necrosis factor- $\alpha$ (TNF- $\alpha$ ) and inflammatory proteins inducible nitric oxide synthase (iNOS) and cyclooxygenase-2 (COX-2)) [3,6].

Carbazole alkaloids are characterized by a tricyclic aromatic basic skeleton consisting of a central pyrrole ring fused with two benzene rings. Phyto-carbazoles are basically derived from 3-methyl carbazole as the common precursor. Carbazoles are privileged scaffolds, often reported in natural products [7], and exhibit a wide spectrum of biological activities, such as anticancer [8], neuroprotective [9], antituberculosis [10], and anti-HIV (Human Immunodeficiency Virus) [11]. Two drugs, Midostaurin and Carvediol, with a carbazole core were approved by the FDA for treating tumors and congestive heart failure, respectively [12].

Phyto-carbazole alkaloids are abundantly found in species of the Rutaceae family, including Murraya koenigii (Curry leaves), Glycosmis pentaphylla (Gin berry), Clausena heptaphylla (Clausena), Clausena excavate (Pink Lime-Berry), Murraya euchrestifolia, Micromelum sp. and Zanthoxylum sp. [13]. Among the naturally occurring phyto-carbazole alkaloids, mahanimbine, koenimbine, koenigicine and clausazoline- $\mathrm{K}$ were reported to possess anti-lipase activity $[14,15]$, while mahanine, pyrayafoline-D and murrafoline-I displayed anticancer activities by inducing apoptosis through activating the caspase-9/caspase-3 pathway [16]. Both natural and synthetic derivatives of carbazole alkaloids have revealed numerous pharmacological activities, such as anticancer [17], antioxidant [18], anti-inflammatory [19], antibacterial [20], antifungal [21], antidiabetic [22], antiangiogenic [23], larvicidal [24], antiplant virus [25], anti-HIV [26], and neuroprotective activities [13]. In particular, carbazolecontaining arylcarboxamides and carbazole thiazoles are inhibitors of $\beta$-secretase (BACE-1: the enzyme responsible for the production of $\beta$-amyloid $(A \beta)$ ) and $A \beta$ formation, respectively $[27,28]$. Several dibenzofuran/carbazole derivatives inhibit acetylcholinesterase (AChE) and $\mathrm{A} \beta$ aggregations [29]. Owing to strong antioxidant and neuroprotective effects towards neurons displayed by $\mathrm{N}$-substituted carbazoles [30], hybrids comprising tacrine and carbazole were developed, with anti-AChE activities [9].

Biogenetically, the phyto-carbazole alkaloids are postulated to originate from the shikimate pathway (Figure 1) [31,32]. As shown in Figure 1, the diverse phyto-carbazole alkaloids identified from nature are classified based on their carbazole or 3-methylcarbazole core structure. Next, in vivo oxidation of the methyl group of the 3-methylcarbazole provides the formyl carbazole or methyl carbazole-3-carboxylate congener structures, which are commonly found in the genera Murraya, Clausena and Glycomis [31]. Moreover, the majority of the more than 330 identified phyto-carbazole alkaloid derivatives from nature are based on 3-methylcarbazole as their common precursor [13].

Due to the immense medicinal properties of phyto-carbazole alkaloids, the present review aims to highlight the pharmacological action mechanisms of important and prevalent phyto-carbazoles from the Rutaceae family in treating the pathophysiology of NDs. Owing to the complex etiology of NDs, a multitarget approach of bioactive compounds in ameliorating disease symptoms may achieve better clinical results. Hence, this review could be a basis for potential future complementary treatment of complex NDs. 
<smiles>O=C(O)C1=C[C@@H](O)[C@H](O)[C@H](O)C1</smiles>

Shikimic acid<smiles>C=CCCCC</smiles>

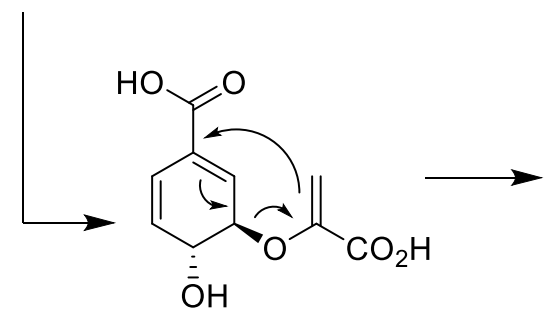

Chorismic acid<smiles>O=C(O)C[C@]1(C(=O)O)C=C[C@@H](O)C=C1</smiles>

Prephenic acid<smiles>Nc1ccccc1C(=O)O</smiles>

Anthralinic acid

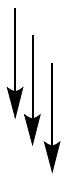

Quinolone Alkaloids<smiles>Nc1ccccc1C(=O)O</smiles>

Anthralinic acid<smiles>O=C(O)C[C@]1(C(=O)O)C=C[C@@H](O)C=C1</smiles>

Prephenic acid<smiles>C=CC(Nc1ccccc1C(=O)O)(C(=O)O)C(=O)OCC</smiles>

Dehydration<smiles>O=C(O)c1ccccc1Nc1ccccc1</smiles>

Decarboxylation

Cyclization<smiles>c1ccc2c(c1)[nH]c1ccccc12</smiles>

Carbazole

\section{C-3 Methylation}<smiles>Cc1ccc2[nH]c3ccccc3c2c1</smiles>

3-Methylcarbazole

Figure 1. Biogenetic pathway in the formation of carbazole and 3-methyl carbazole alkaloids and core structure of the diverse carbazole alkaloids isolated from nature.

\section{Phyto-Carbazole Alkaloids in Neuroprotection}

\subsection{Phyto-Carbazole Alkaloids from the Genus Murraya}

Murraya koenigii is a rich source of phyto-carbazole alkaloids, isolated from the leaves, stem, bark, and root, with promising pharmacological activities [33,34]. Neuroprotective pharmacological activities of the M. koenigii leaf (MKL) extract are also associated with phyto-carbazole alkaloids. When total alkaloidal extract of MKL was administered orally to different groups of mice, a significant improvement in memory scores was observed in the elevated plus maze and passive avoidance apparatus models [35]. Interestingly, reductions in the brain cholinesterase activity ( $\sim 20 \%$ reduction) and BACE-I activity (IC 50 $1.7 \mu \mathrm{g} / \mathrm{mL}$ ) were also observed with MKL alkaloids [35]. The actual phyto-carbazole alkaloids in the above study are yet to be identified, but euchrestine B, bismurrayafoline $\mathrm{E}$ and (+)-mahanine exhibited potent antioxidant activities in 2,2-diphenyl-1-picrylhydrazyl (DPPH) assay $(21.7 \mu \mathrm{M}, 6.8 \mu \mathrm{M}$ and $21.9 \mu \mathrm{M}$, respectively) in comparison to the standards tocopherol, butylated hydroxytoluene (BHT) and ascorbic acid $(27.8 \mu \mathrm{M}, 83.2 \mu \mathrm{M}$ and $4.4 \mu \mathrm{M}$, respectively) [36].

The anti-amnesic potential of MKL was observed in mice fed MKL powder mixed feed [37]. Murrayakonine A, O-methylmurrayamine A and mukolidine isolated from 
M. koenigii leaves exhibited strong anti-inflammatory effects against lipopolysaccharide (LPS) induced human peripheral blood mononuclear cells (PBMCs) by reducing the production of TNF- $\alpha$ and IL-6 [38]. Murrayanol also presented anti-inflammatory potential against human prostaglandin-endoperoxide $\mathrm{H}$ synthase (hPGHS-1) (IC $50109 \mu \mathrm{g} / \mathrm{mL}$ ) and hPGHS-2 (IC $50218 \mu \mathrm{g} / \mathrm{mL}$ ) [39].

Murrayamine-E (at $10 \mu \mathrm{M}$ ), isolated from $M$. koenigii, showed substantial effects on neurite outgrowth. For exploiting the phyto-carbazole skeleton of murrayamine-E as a potential pharmacophore, similar derivatives were synthesized. One of the compounds, 9-benzyl-9H-carbazol-4-ol, revealed robust influences on neurite outgrowth. In addition, it improved memory in APdE9 mice. These results suggest that carbazole derivative 9-benzyl-9H-carbazol-4-ol would be an important compound for ND drug discovery [40].

Microphyltrine, microphyldines A-O and microphyldine $\mathrm{P}$ were isolated from the stem and leaves of M. microphylla [41]. Nitric oxide production induced by LPS in BV-2 microglial cells was inhibited by phyto-carbazole alkaloids from $M$. tetramera and $M$. kwangsiensis [19,42], with $\mathrm{IC}_{50}$ values ranging from 5.1 to $15.1 \mu \mathrm{M}$ [43].

Mahanimbine, a major phyto-carbazole alkaloid from M. koenigii, was reported as an in vitro inhibitor of $\mathrm{AChE}\left(\mathrm{IC}_{50} 0.03 \mathrm{mg} / \mathrm{mL}\right)$ [44]. It also displayed high antioxidant activity $\left(\mathrm{IC}_{50} 33.1 \mu \mathrm{g} / \mathrm{mL}\right.$ ) in comparison to the positive controls: tert-butylhydroquinone (TBHQ), BHT and butylated hydroxyanisole (BHA) ( $\mathrm{IC}_{50} 3.3,4.4$ and $18 \mu \mathrm{g} / \mathrm{mL}$, respectively) [39].

In vivo and in vitro studies confirmed the beneficial approach of the multi-target properties of mahanimbine in $\mathrm{AD}$ treatment, which presented its neuroprotective potentials in SK-N-SH neuroblastoma cells against $100 \mu \mathrm{g} / \mathrm{mL}$ LPS. Interestingly, the pre-treatment of SK-N-SH cells with mahanimbine significantly prevented cell loss and attenuated LPSinduced reactive oxygen species (ROS) formation. Additionally, mahanimbine also inhibited BACE 1 with IC $\mathrm{IC}_{50}$ of $4 \mu \mathrm{g} / \mathrm{mL}$. From an in vivo study, the biochemical analysis of the whole brain of ICR mice detected increased CAT and GRD levels and significant decreases of malondialdehyde (MDA) levels in mahanimbine-treated groups in comparison to the untreated group [45].

In LPS-challenged mice, mahanimbine improved cognition in the Morris water maze (MWM) experiment. It also improved the central cholinergic transmission by increasing acetylcholine (ACh) levels in the brain homogenate $(27.48 \pm 2.44 \mu \mathrm{M}, 24.40 \pm 2.87 \mu \mathrm{M}$, $23.19 \pm 2.62 \mu \mathrm{M})$ through $\mathrm{AChE}$ inhibition. Additionally, mahanimbine greatly reduced $\mathrm{A} \beta_{1-40}$, pro-inflammatory cytokines (IL- $\beta \beta$ and TNF- $\alpha$ ), the total activity of COX, and expression of the COX-2 gene in LPS-induced group. These findings support the neuroprotective activity of mahanimbine against LPS-induced neuroinflammation [46]. It was observed that mahanimbine reduced oxidative stress through nuclear factor erythroid-2related factor 2 (Nrf2)-dependent induction of antioxidant enzymes (SOD and CAT) and by subduing the expressions of proinflammatory cytokines (Nuclear factor kappa: NF- $\mathrm{kB}$, TNF- $\alpha, I L-1 \beta)$ and A $\beta$ accumulations [35,47-49].

Murrayanine is the first reported phyto-carbazole alkaloid from the stem bark of M. koenigii with potential antioxidant properties [50]. When anti-inflammatory effects were investigated both in vitro and in vivo, a reduction of $\mathrm{NO}$ (a prominent pro-inflammatory molecule released in both acute and chronic inflammatory conditions) was observed [51]. In addition, pro-inflammatory cytokines (IL- 6 and TNF- $\alpha$ ) were also decreased in both LPS-stimulated RAW 264.7 cells and murine peritoneal macrophages. Moreover, iNOS and COX-2 protein expressions, as well as their downstream product, prostaglandin E2 (PGE2), were also decreased effectively in murine macrophage RAW 264.7 cells. Murrayanine also suppressed the inhibitor of nuclear factor kappa $B(I-\kappa \beta)$ phosphorylation and NF- $k B$ activity in LPS-activated RAW 264.7 cells. The NF- $k \beta$ pathway is important for preserving synaptic plasticity and balancing between learning and memory. Therefore, any impairment in the pathways associated with NF- $\kappa \beta$ signaling cause altered neuronal dynamics [52]. Additionally, administration of murrayanine in a systemic inflammation mouse model inhibited pro-inflammatory cytokines and also increased the survival rate in LPS-challenged mice. 
From in silico studies using random forest (RF) models, several phytocompounds were evaluated for their interaction potentials against COX-1 and COX-2 through molecular docking, dynamics simulation and free energy calculations [53]. Girinimbine from M. koenigii was selective towards COX-2, which was supported by the experimental studies of inhibiting COX in an anti-inflammation model. Cytotoxicity assessment of girinimbine against the breast cancer cell line MDA-MB-231 also supported it as a COX-2 inhibitor $\left(\mathrm{IC}_{50}\right.$ $0.006 \mu \mathrm{g} / \mathrm{mL})[53]$.

Furthermore, girinimbine inhibited inflammation in vitro as well as in vivo. In LPS/ INF- $\gamma$ induced RAW 264.7 cells, significant dose-dependent girinimbine inhibitions of NO production and NF- $\kappa \beta$ translocation from the cytoplasm to nucleus were observed [54]. Girinimbine revealed its considerable antioxidant activity, equivalent to $82.17 \pm 1.88 \mu \mathrm{M}$ of Trolox at $20 \mu \mathrm{g} / \mathrm{mL}$. In a carrageenan-induced peritonitis mouse model, oral pre-treatment of girinimbine reduced pro-inflammatory cytokine levels (IL-1 $\beta, \mathrm{TNF}-\alpha)$ in the peritoneal fluid [54]. In a mice model of ethanol-induced gastric ulcers, GSH and MDA levels were restored in the girinimbine treatment group with decreased levels of proinflammatory cytokines (TNF- $\alpha$ and IL-6) and iNOS. Girinimbine could also selectively inhibit COX2 [55]. Still, no study has reported the direct neuroprotective effects of girinimbine. The anti-inflammatory and antioxidant potential of girinimbine in neurodegenerative diseases should be investigated.

Structures of the phyto-carbazole alkaloids isolated from $M$. koenigii with potential neuroprotective effects against neurodegenerative diseases are presented in Figure 2.

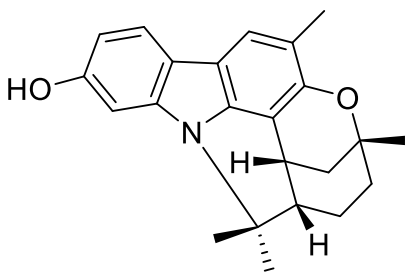

Murrayamine E<smiles>Cc1cc2c([nH]c3ccccc32)c2c1OC(C)(C)C=C2</smiles>

Girinimbine<smiles>CC(C)=CCCC1(C)C=Cc2c(c(C)cc3c2[nH]c2ccccc23)O1</smiles>

Mahanimbine<smiles>COc1cc(C=O)cc2c1[nH]c1ccccc12</smiles>

Murrayanine<smiles>COc1cc2[nH]c3c(C/C=C(\C)CCC=C(C)C)c(O)ccc3c2cc1C</smiles>

Murrayanol<smiles>CC(C)=CCC[C@]1(C)C=Cc2c(c(C)cc3c2[nH]c2cc(O)ccc23)O1</smiles>

(+)-Mahanine<smiles>COc1ccc2c([nH]c3cc(O)c(C)cc32)c1C/C=C(/C)CCC=C(C)C</smiles>

Euchrestine B

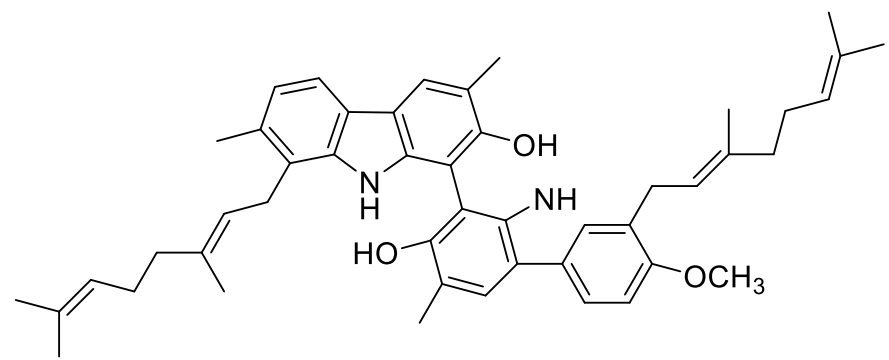

Bismurrayafoline $\mathrm{E}$

Figure 2. Potential neuroprotective phyto-carbazole alkaloids from Murraya koenigii. 


\subsection{Phyto-Carbazole Alkaloids from the Genus Clausena}

Structures of the phyto-carbazole alkaloids isolated from various Clausena species with potential neuroprotective effects against NDs are presented in Figure 3. Phytocarbazole alkaloid clausenanisines $\mathrm{A}-\mathrm{F}$ and clausevestines were isolated from the fruits of C. anisumolens [56] and from the stem and leaves of C. vestita [57], respectively. Various prenylated carbazole alkaloids presented a significant inhibition $\left(\mathrm{IC}_{50} 0.63-8.3 \mu \mathrm{M}\right)$ of $\mathrm{NO}$ production in mouse macrophage RAW 264.7 cells by LPS induction, with hydrocortisone $\left(\mathrm{IC}_{50} 3.8 \mu \mathrm{M}\right)$ as the positive control [57,58]. Clauemarazoles A-G and its derivatives were isolated from the stems of C. emarginata. Among them, clauemarazole E, clausine $\mathrm{K}$ and clausine $\mathrm{O}$ exhibited inhibitory abilities on LPS-induced $\mathrm{NO}$ production $\left(\mathrm{IC}_{50} 10.91,4.6\right.$ and $6.4 \mu \mathrm{M}$, respectively) [59]. Still, no direct study has been conducted on the neuroprotective potential. Similarly, phyto-carbazoles from C. dunniana showed weak inhibitory effects on NO production stimulated by LPS in BV-2 microglial cells $\left(\mathrm{IC}_{50}>50 \mu \mathrm{M}\right)$ [60].

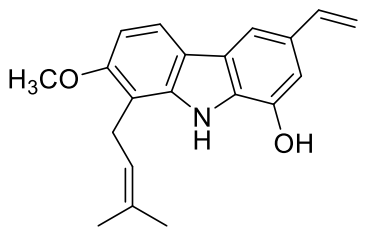

Clausenalenine A<smiles>COc1cccc2c1[nH]c1cc(O)c(C=O)cc12</smiles>

Clausine A<smiles>COc1ccc2c([nH]c3c(O)cc(C)cc32)c1CC=C(C)C</smiles>

Murrayafoline B<smiles>COc1cc2c(cc1O)[nH]c1c(O)cc(C=O)cc12</smiles>

Clausine $J$<smiles>COc1ccc2c(c1)[nH]c1cc(O)c(C)cc12</smiles>

Isomurrayafoline B<smiles>COc1ccc2[nH]c3c(OC)cc(C=O)cc3c2c1</smiles>

Clausine I<smiles>CC(C)=CCc1c(O)ccc2c1[nH]c1cc(O)c(C)cc12</smiles>

Euchrestine A<smiles>COc1cc(C=O)cc2c1[nH]c1cc(O)ccc12</smiles>

Clausine $Q$<smiles>O=Cc1cc(O)c2[nH]c3ccc(O)cc3c2c1</smiles>

Clausine Z<smiles>C/C(=C\CC[C@@H]1C=Cc2c(c(C)cc3c2[nH]c2ccccc23)O1)CO</smiles>

Clauselansiumine A<smiles>Cc1cc2c([nH]c3ccccc32)c2c1O[C@@H](CCC(O)C(C)(C)O)C=C2</smiles>

Clauselansiumine B<smiles>COc1c2c(cc3c1[nH]c1ccccc13)C1CCC(C)(O2)OC1(C)C</smiles>

Claulansine A<smiles>COc1ccc2[nH]c3c4c(c(C=O)cc3c2c1)OC(C)(C)C=C4</smiles>

Claulansine F<smiles>COc1cc2c(cc1O)[nH]c1c(CC=C(C)C)c(O)c(C=O)cc12</smiles><smiles>COc1cc2c(cc1O)[nH]c1c(O)c(CC=C(C)C)c(C=O)cc12</smiles>

Claulansine I<smiles>COc1cc2c(cc1O)[nH]c1cc(O)c(C=O)cc12</smiles>

Claulansine $\mathrm{J}$

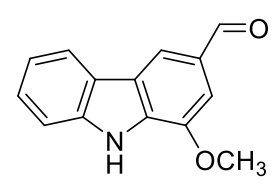

Murrayanine

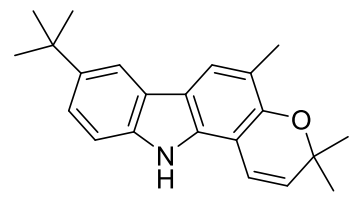

CZ-7

(Synthetic derivative of Claulansine F)

Figure 3. Potential neuroprotective phyto-carbazole alkaloids from the species of the genus Clausena. 
Since many extracts from C. lansium possessed strong antioxidant activities in vitro [61], the neuroprotective and cognitive enhancing effects of various concentrations of peel crude extract were investigated on a rat model of focal cerebral ischemia. A significant reduction of brain infarction and oxidation indices, a restoration of memory, a revived level of antioxidants, and enriched survival and cholinergic neurons were witnessed in the hippocampal region in vivo [61].

Hydroethanolic extract of the stems and leaves of C. lenis exhibited significant neuroprotective activities against the induced apoptosis with 6-hydroxydopamine (6-OHDA) in human neuroblastoma SH-SY5Y cells (SH-SY5Y, EC $5012.86 \mu \mathrm{g} / \mathrm{mL}$ ). Eight phytocarbazole alkaloids_clausenalenine A, murrayafoline B, isomurrayafoline B, euchrestine A, clausine A, clausine J, clausine I and clausine Q-possessed substantial neuroprotective effects $\left(\mathrm{EC}_{50} 0.68\right.$ to $\left.18.76 \mu \mathrm{M}\right)$ against 6-OHDA-induced apoptosis in SH-SY5Y by 6-hydroxydopamine. Hence, regular consumption of these fruits may protect against Parkinson's disease (PD) [62].

Clausine $Z$ from C. excavata showed potent inhibition of recombinant Cyclin-dependent kinase 5 (CDK5) ( $\left.\mathrm{IC}_{50} 0.51 \mathrm{mM}\right)$ in a filter plate assay in comparison to the standard inhibitor: butyrolactone I ( $\left.\mathrm{IC}_{50} 0.11 \mathrm{mM}\right)$. In cell-based studies, clausine Z protected cerebellar granule neurons against free radical-induced apoptosis, with an $\mathrm{EC}_{50}$ of $1.1 \mathrm{mM}$ in comparison to the standard butyrolactone I $\left(\mathrm{EC}_{50} 3 \mathrm{mM}\right)$ [63]. Studies have revealed that neuroprotection is correlated with the inhibition of neuron-specific CDK5 [64]. For neurite outgrowth and cortical lamination, CDK5 and its neuron-specific activator p35 are essential [65]. Proteolytic cleavage of CDK 5 activator p35 by calpain led to the formation and accumulation of p25 in the brain of AD patients [66]. This proteolytic cleavage resulted in prolonged activation of cdk5 and subsequently hyper-phosphorylation of tau by the p25/cdk5 kinase, in turn disrupting the cytoskeleton and promoting apoptosis of primary neurons [67]. The p25 is neurotoxic in nature and results in apoptosis [68]. Moreover, it is seen as a downstream regulator of $A \beta$ [67]. Thus, small molecule inhibitors of CDK5 could be important contenders for the therapeutic development of neurodegenerative diseases, as they protect against p25 neurotoxicity [69]. Hence, clausine $Z$ and derivatives may present important therapeutic values in neurodegenerative diseases, such as AD, PD and amyotrophic lateral sclerosis (ALS).

Geranylated phyto-carbazole alkaloids (clauselansiumines A-B) along with other carbazole alkaloids from the stem and leaves of $C$. lansium revealed remarkable neuroprotective effects ( $\mathrm{EC}_{50} 0.48$ to $12.36 \mu \mathrm{M}$ ) against 6-OHDA-induced apoptosis in SH-SY5Y cells [70]. The protective effect of phyto-carbazoles $(10 \mu \mathrm{M})$ was also reported on primary neurons against oxygen glucose deprivation (OGD) injury [71].

Ten new phyto-carbazole alkaloids (claulansines A-J) and their analogues were isolated from C. lansium and were assessed for their neuroprotective effect [72]. Claulansine A, F, H-J, and murrayanine were found to be neuroprotective at $10 \mu \mathrm{M}$ [72]. All these alkaloids displayed prominent neuroprotective activity $\left(\mathrm{EC}_{50} 0.36\right.$ to $\left.10.69 \mu \mathrm{M}\right)$ in comparison to the standard curcumin $\left(\mathrm{EC}_{50} 5.8 \mu \mathrm{M}\right)$ in 6-OHDA-induced apoptosis in SH-SY5Y cells [73]. Structure activity relationship (SAR) demonstrated the importance of the aldehyde group or hydroxymethyl group at C-3 position in noteworthy neuroprotective effects. Among them, claulansine F (Clau F), a pyrano[3,2-a] carbazole alkaloid, revealed protection against sodium nitroprusside (SNP)-induced apoptosis in pheochromocytoma (PC12) cells [74], which exerted a significant effect on hydroxyl free radical scavenging and mitochondrial integrity. Based on the encouraging neuroprotective activity of claulansine $\mathrm{F}$, its analogues were synthesized, and their neuroprotective effects were studied against hydrogen peroxide $\left(\mathrm{H}_{2} \mathrm{O}_{2^{-}}\right)$and OGD-induced injury in PC12 cells and primary cortical neurons [75]. The SAR showed a stronger neuroprotective effect when the methyl group was present at C-3 and at C-6, with no substitution at N-9, in comparison to the N-alkyl substitution. In contrast, with the presence of aldehyde at C-3 and the same group at C-6, N-alkyl substitution exhibited much stronger neuroprotective effects than without substitution at N-9. In addition, lipophilic groups at C-6 displayed stronger activities (CZ-7, with a 
t-Bu at C-6). CZ-7 exhibited the strongest neuroprotective effects in vitro and at lower doses efficiently protected against ischemic stroke in a rat model of Middle Cerebral Artery Occlusion (MCAO). Furthermore, CZ-7 showed stronger free radical scavenging capacity than Edaravone (EDA), which was therapeutically used as a strong antioxidant and neuroprotective agent in ALS. Most importantly, CZ-7 could pass through the blood-brain barrier (BBB) in rats with 4.3-fold higher concentrations in brain than plasma [75]. These results suggest the importance of groups at C-3, C-6 and N-9; the lipophilic groups in the compounds are the crucial factors for neuroprotective activity of carbazoles [75].

In another study, oral treatment of CZ-7 ameliorated cognitive impairment in rats with permanent occlusion of bilateral common carotid arteries (2VO) [73]. Morris water maze tests revealed that CZ-7 considerably reduced the escape latency in 2VO rats. Morphological studies using Nissl and terminal deoxynucleotidyl transferase dUTP nick end labelling (TUNEL) staining showed that the administration of CZ-7 markedly diminished the pathological changes in the CA1-CA3 area of the hippocampus, including neuronal cell loss, nuclear shrinkage, and dark staining of neurons, and significantly decreased chronic cerebral hypoperfusion-induced cell loss. Additionally, CZ-7 significantly improved the white matter lesions as seen in Klüver-Barrera staining. CZ-7 administration significantly decreased oxidative stress in the CA1-CA3 area of the hippocampus from 8-hydroxydeoxyguanosine (8-OHdG) and ROS immunofluorescent analyses. The double immunofluorescent staining of Nrf2 and the elevated expressions of oxidative stress proteins Heme oxygenase-1 (HO-1) and NAD(P)H: quinone oxidoreductase 1 (NQO1) suggested that CZ-7 recovered the oxidative stress through the Nrf2 pathway [73].

Clau F-donepezil (a FDA-approved AChE inhibitor) hybrids were synthesized through additional development to evaluate the neuroprotective potential. The benzylpiperidine fragment of donepezil interacted with the catalytic domain of AChE. For free-radical scavenging activity, the indanone moiety was replaced by Clau F (or its analogue CZ-7 fragments). The Clau F-donepezil hybrids exhibited potent $\mathrm{AChE}$ inhibition $\left(\mathrm{IC}_{50} 1.63-\right.$ $4.62 \mu \mathrm{M})$ [73]. Furthermore, (E)-3-(8-(tert-Butyl)-3,3-dimethyl-3,11-dihydropyrano[3,2a] carbazol-5-yl)-N-((1-(2-chlorobenzyl) piperidin-4-yl) methyl) acrylamide (Compound 6bd) demonstrated superior neuroprotective effects in comparison to Clau $\mathrm{F}$ against OGD/reoxygenation (OGD/R). Additionally, the compound 6bd displayed good BBB penetration (Permeability: Pe $\times 10^{-6} \mathrm{~cm} \cdot \mathrm{s}^{-1}$ ) in parallel artificial membrane permeation assay (PAMPA) [25].

\subsection{Phyto-Carbazole Alkaloids from Glycomis pentaphylla}

The genus Glycosmis is considered as a rich source of potentially biologically active secondary metabolites, such as alkaloids, flavonoids, phenolic glycosides, quinones and terpenoids. Plants in the genus Glycosmis were used in traditional medicine for the treatment of various diseases, like anxiety, cancer, snake bites and joint pain [76-79]. Structures of the phyto-carbazole alkaloids isolated from G. pentaphylla are presented in Figure 4.

Phytochemical analyses shows the isolation and elucidation of glycozolidol, glycozolicine, 3-formyl-9H-carbazole and glycosinine from the roots of G. pentaphylla [80-82], while 4-(7-hydroxy-3-methoxy-6-methyl-9H-carbazol-4-yl)but-3-en-2-one, bisglybomine $\mathrm{B}$, biscarbalexine A, carbazole-indole-type dimeric alkaloids, and glycosmisines A and B were isolated from the stem of G. pentaphylla $[83,84]$.

The methanolic extract of $G$. pentaphylla exhibited significant dual AChE $\left(\mathrm{IC}_{50}\right.$ $325.1 \pm 0.91 \mu \mathrm{g} / \mathrm{mL})$ and butyryl cholinesterase (BChE) effects $\left(\mathrm{IC}_{50} 42.1 \pm 3.30 \mu \mathrm{g} / \mathrm{mL}\right)$. Furthermore, the extract showed radical scavenging ability in 2,2-diphenyl-1-picrylhydrazyl $(\mathrm{DPPH})$ assay $\left(\mathrm{IC}_{50} 95.6 \pm 0.68 \mu \mathrm{g} / \mathrm{mL}\right)$ and a lipid peroxidation inhibitory effect $\left(\mathrm{IC}_{50}\right.$ $288.7 \pm 0.91 \mu \mathrm{g} / \mathrm{mL}$ ) [85]. The total crude alkaloid extract of $G$. pentaphylla showed antioxidant potential in the DPPH assay $\left(\mathrm{IC}_{50} 966.93 \mu \mathrm{g} / \mathrm{mL}\right)$, ferric reducing antioxidant power (FRAP) (IC $50510.81 \mu \mathrm{g} / \mathrm{mL}$ ), 2,2'-azino-bis (3-ethylbenzothiazoline-6-sulfonic acid) (ABTS) assay ( $\left.\mathrm{IC}_{50} 400.47 \mu \mathrm{g} / \mathrm{mL}\right)$, hydroxyl free radical $(\mathrm{OH} \cdot)$ assay $\left(\mathrm{IC}_{50} 1805.28 \mu \mathrm{g} / \mathrm{mL}\right)$ and 
NO assay ( $\mathrm{IC}_{50} 1426.50 \mu \mathrm{g} / \mathrm{mL}$ ). Thus, these phyto-carbazole alkaloids were the potential therapeutic target for NDs such as AD, PD and other oxidative stress-related diseases [86].<smiles>COc1ccc2[nH]c3cc(OC)c(C=O)cc3c2c1</smiles>

Glycozolidal<smiles>COc1cc2[nH]c3ccccc3c2cc1C=O</smiles>

Glycozinine<smiles>COc1cc2[nH]c3ccc(O)cc3c2cc1C</smiles>

Glycozolidol<smiles>COc1ccc2[nH]c3ccc(C)cc3c2c1</smiles>

Glycozolicine<smiles>O=Cc1ccc2[nH]c3ccccc3c2c1</smiles>

3-Formyl-9H-carbazole<smiles>CC(C)=CCc1cccc2c([C@]3(C)[C@H](O)CO[C@H]3c3c(O)c(C)cc4c3[nH]c3ccc5c(c34)C=CC(C)(C)O5)c[nH]c12</smiles>

Glycosmisine A

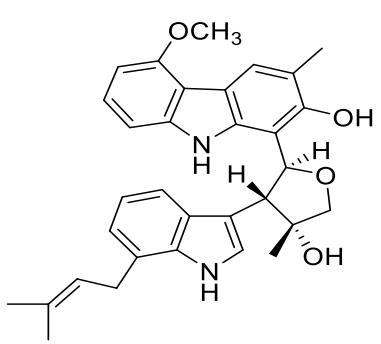

Glycosmisine B<smiles>COc1ccc2[nH]c3cc(O)c(C)cc3c2c1/C=C/C(C)=O</smiles>

4-(7-hydroxy-3-methoxy-6-methyl-9Hcarbazol-4-yl)but-3-en-2-one

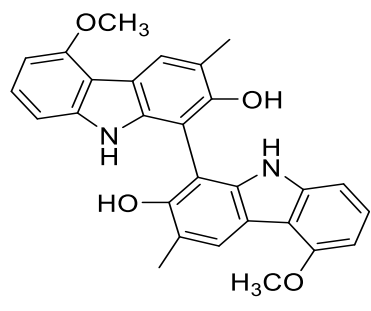

Biscarbalexine A

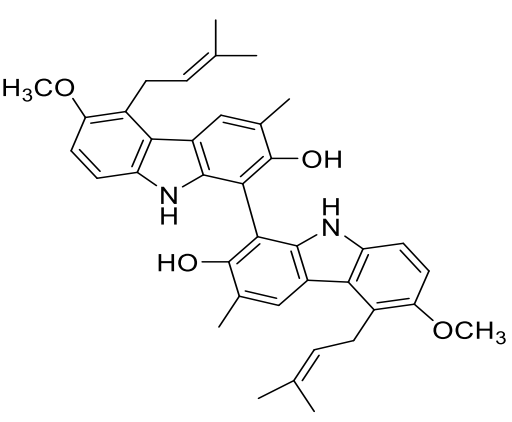

Bisglybomine B

Figure 4. Potential phyto-carbazole alkaloids from Glycomis pentaphylla.

\subsection{Phyto-Carbazole Alkaloids from Micromelum}

Micromelum is a rich source of bioactive secondary metabolites. Methylene chloride extract of the stem bark of M. hirsutum is rich in phyto-carbazole alkaloids, including 3-methylcarbazole, 3-formylcarbazole, lansine, micromeline, 3-formyl-6-methoxycarbazole and methyl carbazole-3-carboxylate, and some of these have displayed anti-tuberculosis activity [87]. Structures of the phyto-carbazole alkaloids isolated from the species of the genus Micromelum are presented in Figure 5.

Two phyto-carbazole alkaloids, 2,7-dihydroxy-3-formyl-1-(3-methyl-2-butenyl) carbazole and 7-methoxy heptaphylline, have been isolated from the roots of M. glanduliferum, which are used as chemotaxonomic markers to differentiate this plant from other Micromelum species [88]. Koenimbine, koenine, koenigine and koenidine were isolated from the leaves and young stems of M. zeylanicum [89]. Additionally, mahanine from the leaves of M. minutum presents vast therapeutic effects, such as anticancer, anti-mutagenicity, antimicrobial and anti-inflammatory $[90,91]$. Phyto-carbazole alkaloids glycozolinol and methyl carbazole-3-carboxylate were isolated from the leaves of M. integerrimum [92]. However, in spite of the immense pharmaceutical importance of phyto-carbazole alkaloids from Micromelum, no study has been conducted on the neuroprotective action of Micromelum species [93]. 


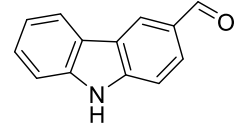

3-Formyl-9H-carbazole

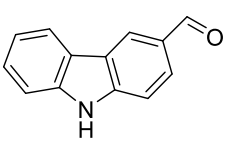

3-Methylcarbazole

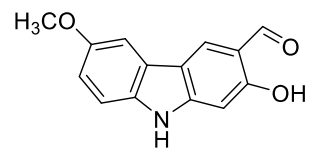

Lansine

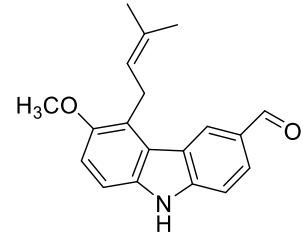

Micromeline

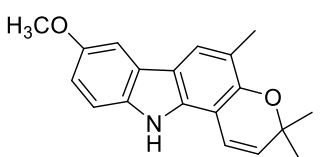

Koenimbine

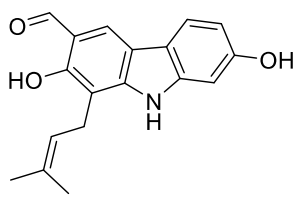

2,7-dihydroxy-3-formyl-1(3-methyl-2-butenyl) carbazole

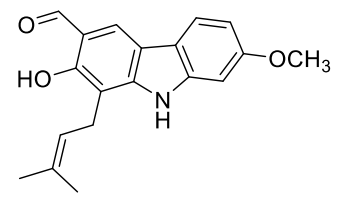

7-Methoxy heptaphylline

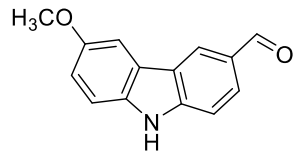

3-Formyl-6-methoxycarbazole

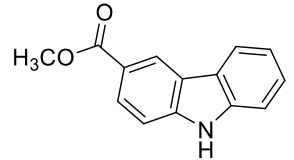

Methyl carbazole-3-carboxylate

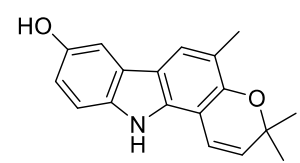

Koenine

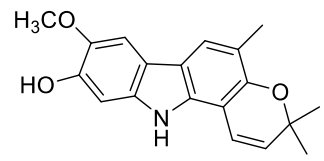

Koenigine

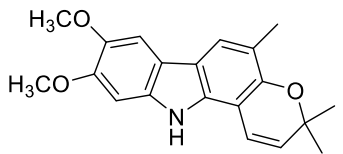

Koenigicine

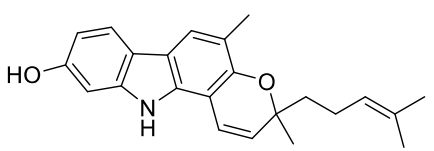

Mahanine

Figure 5. Potential phyto-carbazole alkaloids from the species of the genus Micromelum.

\subsection{Carbazole Alkaloids from Zanthoxylum}

Zanthoxylum species (syn. Fagara species) are widely used as food and in traditional systems of medicine for treating inflammation, pain, hypertension and neurological diseases [94]. Structures of the phyto-carbazole alkaloids isolated from Zanthoxylum species with potential neuroprotective effects against NDs are presented in Figure 6. The phytochemicals responsible for the biological activities of some of the species have yet to be identified.

Isolated Zanthoaustrones A-C from the roots of Z. austrosinense [95] significantly inhibited NO production ( $\mathrm{IC}_{50} 1.59 \pm 0.11,1.29 \pm 0.06,0.89 \pm 0.05 \mu \mathrm{M}$, respectively) in comparison to hydrocortisone ( $\left.\mathrm{IC}_{50} 4 \mu \mathrm{M}\right)$. Two prenylated alkaloids 2,6,7-trimethoxy-8(3-methyl-2-butenyl) carbazole-3-carbaldehyde and methyl-2,6,7-trimethoxy-8-(3-methyl2-butenyl) carbazole-3-carboxylate were isolated from ethyl acetate soluble fraction of $Z$. armatum, which demonstrated substantial antioxidant potential in DPPH free radical scavenging assay [96]. From the ethanol-soluble extract of $Z$. fagara bark, two novel furocarbazole alkaloids with antibacterial activity, 4-methoxy- $10 \mathrm{H}$-furo[3,2-a] carbazole and $10 \mathrm{H}$-furo[3,2-a] carbazole, were isolated [96,97]. Han et al. [98] evaluated the antioxidant, antidiabetic, and neuroprotective activity against high glucose-induced cytotoxicity of Z. piperitum (ZP) and Z. schinifolium (ZS) extracts. The extracts displayed strong antioxidant potential in ABTS/DPPH assays, and MDA contents were significantly reduced. ZP inhibited carbohydrate hydrolysis ( $\alpha$-glucosidase and $\alpha$-amylase) more efficiently than $\mathrm{ZS}$ in antidiabetic tests. Interestingly, ZS in comparison to ZP decreased anti-advanced glycation end-products (AGE) more effectively. AGEs have an important role in the progression and pathogenesis of $\mathrm{AD}$, as $\mathrm{A} \beta$ aggregation is accelerated in the presence of AGEs [99]. The content of AGEs is more in neurofibrillary tangles (NFTs) and plaques, as suggested by immunohistochemical studies [100]. Additionally, both ZP and ZS effectively protect human-derived neuronal cells from high glucose-induced cytotoxicity, indicating the neuroprotective nature of the plants. In a recent study [101], pericarp of Z. schinifolium (ZSP) unveiled effective DPPH $\left(\mathrm{IC}_{50} 75.6 \pm 6.1 \mu \mathrm{g} / \mathrm{mL}\right)$ and ABTS $\left(\mathrm{IC}_{50}=57.4 \pm 6.0 \mu \mathrm{g} / \mathrm{mL}\right)$ radical scavenging activities. ZSP also inhibited the release of 
pro-inflammatory cytokines, IL-1 $\beta$ (IC $\left.\mathrm{IC}_{50} 134.4 \pm 7.8 \mu \mathrm{g} / \mathrm{mL}\right), \mathrm{IL} 6\left(\mathrm{IC}_{50} 262.8 \pm 11.2 \mu \mathrm{g} / \mathrm{mL}\right.$ ) and TNF- $\alpha\left(\mathrm{IC}_{50} 223.8 \pm 5.8 \mu \mathrm{g} / \mathrm{mL}\right)$.<smiles>COc1ccc2[nH]c3c(O)cc(C(=O)O)cc3c2c1</smiles>

Zanthoaustrone A<smiles>COC(=O)c1ccc2[nH]c3ccc(O)cc3c2c1</smiles>

Zanthoaustrone B

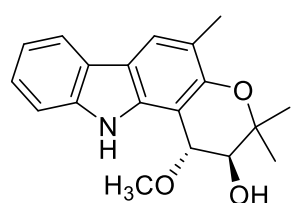

Zanthoausthrone C

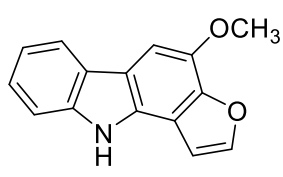

4-Methoxy-10H-furo[3,2-a] carbazole<smiles>COC(=O)c1cc2c(cc1OC)[nH]c1c(CC=C(C)C)c(OC)c(OC)cc12</smiles>

Methyl-2,6,7-trimethoxy-8-(3-methyl-2-butenyl) carbazole-3-carboxylate

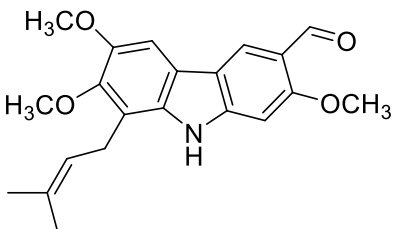

2,6,7-trimethoxy-8-(3-methyl-2-butenyl) carbazole-3-carbaldehyde

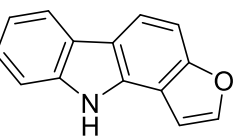

10H-furo[3,2-a] carbazole

Figure 6. Potential neuroprotective phyto-carbazole alkaloids from the species of the genus Zanthoxylum.

The methanolic and ethyl acetate extracts of $Z$. capense root exhibited neuroprotective effects in rotenone-elicited neuronal injury in SH-SY5Y. Pre-treatment of SH-SY5Y cells with the extracts significantly reduced ROS generation and improved intracellular glutathione levels. Moreover, the extracts inhibited rotenone-induced activation of caspase-3 and subsequent apoptosis. Comparatively, methanol extract displayed better neuroprotective activity than ethyl acetate extract [102].

Z. bungeanum is another popular spice in East and Southeast Asia [103], which is used to treat forgetfulness and other symptoms in Chinese traditional medicine [104]. Different Z. bungeanum extracts (water, volatile oil, petroleum ether and methylene chloride) were prepared to evaluate its role in cognitive improvement in D-galactose-induced aging mice [105]. The weakened memory was considerably alleviated after water and volatile oil extract treatment. These extracts also protected against neuron damage in the hippocampus by D-galactose induction. Additionally, treatment with water and volatile oil extracts of Z. bungeanum facilitated the recovery of oxidative stress parameters (SOD, CAT, GSH, MDA) and oxidative stress response genes (Nrf2 and HO-1) in the mouse brain. Furthermore, activation of the phosphoinositide 3-kinase (PI3K)/protein kinase B (Akt) pathway increased the expression of B-cell lymphoma 2 (Bcl2)-associated $\mathrm{X}$ apoptosis regulator (Bax), with a concomitant reduction in the expression of (Bcl2) in the mouse brain [105]. The important role of the PI3K/AKT signalling pathway in neurogenesis, neuronal proliferation and synaptic plasticity is very well ellucidated [106]; it also regulates the expression of $\mathrm{Bcl}-2$, Bax and other related proteins [107]. Additionally, the activation of the PI3K/AKT pathway promotes the growth of dopamine neurons by inhibiting apoptosis [108,109], thereby playing a neuroprotective role in the treatment of $\mathrm{AD}$ and $\mathrm{PD}$.

Activation of Nrf2 is an attractive target for the prevention of AD [110], as its levels are reported to decrease in AD. Hence, it could be suggested that $Z$. bungeanum extracts are promising agents for the prevention of aging-related cognitive dysfunction and neurological deficits [105]. Additionally, the ethyl acetate fraction of the Z. bungeanum leaf exhibited the strongest ABTS and DPPH radical scavenging activities in comparison to chloroform, water fractions and crude extract in vitro. The ethyl acetate fraction protected PC12 cells against hydrogen peroxide-induced cytotoxicity [111]. Similarly, methanol:chloroform (1:4) extract of the Z. piperitum leaf was a potent radical scavenger and reducing agent, which 
also displayed protective effects against $\mathrm{H}_{2} \mathrm{O}_{2}$-induced neurotoxicity in a concentrationdependent manner in PC12 cells [112].

Different species of Zanthoxylum (Z. fagara, Z. rhoifolium, Z. monophylla and Z. quinduensis) exhibited considerable antioxidant and AChE inhibitory potential $(116.8,107.4,10.2$ and $123.0 \mu \mathrm{g} / \mathrm{mL}$, respectively) in comparison to the standard, galantamine $(4 \mu \mathrm{g} / \mathrm{mL})$ [113], which was due to the presence of alkaloids and other phytochemicals. In addition, methanolic and ethyl acetate root extracts of $Z$. davyi displayed potent anti-AChE activity ( $\mathrm{IC}_{50}$ $0.01 \pm 0.004 \mathrm{mg} / \mathrm{mL}$ and $0.011 \pm 0.002 \mathrm{mg} / \mathrm{mL}$, respectively) [114].

Another study elaborated the role of hydro ethanolic extract of Z. alatum (HEZA) in ameliorating scopolamine-induced amnesia in rats by targeting multiple pathways for cognition enhancement [115]. HEZA displayed AChE inhibition, antioxidant effects and inhibition of neuroinflammation (TNF- $\alpha$, IL-1 $\beta$ and IL-10) in the hippocampus. Pretreatment with HEZA considerably down-regulated the expression of $N F \kappa B$, Tau, Bax and Caspase-3, with simultaneous up-regulation of Nrf2, HO-1, PP2A (serine/threonine protein phosphatase $2 \mathrm{~A}$ ), BDNF (brain-derived neurotrophic factor) and TrkB (Tropomyosin receptor kinase B) genes in the hippocampal region [115]. HEZA exhibited antioxidant activity through up-regulating Nrf2-mediated HO-1 expressions. The phosphorylation and dephosphorylation of Tau were regulated by many proteinases, such as $P P 2 A$. It was demonstrated that endogenous $P P 2 A$ was reversibly inhibited during oxidative stress [116]. Next, since BDNF is an important manager of synaptogenesis and synaptic plasticity, the increased levels of BDNF by HEZA could help with memory enhancement [117]. Hence, $Z$. alatum extract revealed positive effects on cognition, and it is a potential candidate for drug development for NDs.

Interestingly, the majority of the identified phyto-carbazole alkaloids in Figures 2-6 originated from 3-methylcarbazole as their mutual precursor, and the oxidation product of 3-methylcarbazole resulted in 3-formyl or 3-carboxyl structures (Figures 2-6) [13,31,32]. The predominant number of the derived phyto-carbazoles from 3-methylcarbazole [13] include the $\mathrm{C}_{-13}$-type 3-methylcarbazoles, represented by 3-methylcarbazole, glycozolidol and glycozolicine; the $\mathrm{C}_{-13}$-type 3 -formylcarbazoles, such as 3-formylcarbazole, lansine, glycozine and murrayanine; the $\mathrm{C}_{-13}$-type 3 -carboxylcarbazole derivatives, including methyl carbazole-3-carboxylate and zanthoaustrone A and B; the C-18-type 3-methylcarbazole alkaloids, such as girinimbine, koenine, koenigine, euchrestine $\mathrm{A}$ and murrayafoline $\mathrm{B}$; the $\mathrm{C}_{-18}$-type 3-formylcarbazoles, represented by 7-methoxyheptaphylline, claulansine $\mathrm{F}$, and claulansine $\mathrm{H}$; the $\mathrm{C}_{-18}$-type 3-carboxylcarbazoles, represented by methyl-2,6,7-trimethoxy8-(3-methyl-2-butenyl)carbazole-3-carboxylate; the C-23-type 3-methylcarbazoles, such as mahanine and mahanimbine; and the $\mathrm{C}_{-23}$-type 3-formyl derivatives. Dimeric phytocarbazole alkaloids, including bismurrayafoline $\mathrm{E}$, glycosmisine $\mathrm{A}$ and $\mathrm{B}$, biscarbalexine $\mathrm{A}$ and bisglybomine $B$, were also reported as potential neuroprotective agents from the genus Rutaceae. With the diversity of the phyto-carbazole structures reported (Figures 2-6), the identification of a specific pharmacophore responsible for the reported biological activities, including neuroprotective effects, may be a challenge. However, the presence of the aldehyde or hydroxymethyl group at the C-3 position may contribute to the neuroprotective activity, based on a previous structure activity relationship (SAR) study [74]. An SAR report on the synthetic derivatives of claulansine F (Figure 3) showed a stronger neuroprotective effect with methyl groups at C-3 and C-6 positions. $N$-9-alkylation resulted in decreased activity. In comparison, substitution of an aldehyde group at C-3 and C-6 positions, including a $N$-9-alkylated moiety, showed stronger neuroprotective effects. Thus, groups at C-3, C-6 and N-9, along with the lipophilic groups, were crucial for neuroprotective activity of the carbazole [75] as specified in Section 2.2. However, a deeper understanding of SAR studies of the isolated phyto-carbazole alkaloids from nature would be worth exploring.

\section{Conclusions and Future Perspectives}

Researchers all over the world are aiming to benefit from the immense natural chemical diversity of plants against a diversity of pharmacological targets. A number of accomplish- 
ments have been documented in finding new entities from the nature; several candidates have been further developed into new drugs, while others have served as a stepping stone for further drug discovery. Table 1 and Figure 7 summarize the neuroprotective activities of Rutaceae family plant extracts.

Table 1. Neuroprotective mechanism displayed by Rutaceae family plant extracts and phytocarbazole alkaloids.

\begin{tabular}{|c|c|c|c|}
\hline Plant/Carbazole Alkaloid & Mechanism of Neuroprotection & Study & Refs \\
\hline Murraya koenigii leaf (MKL) & $\begin{array}{c}\text { Increased ACh } \\
\text { Increased GPx, GSH, GRD, SOD, CAT } \\
\text { Decreased LPO, NO } \\
\text { Anti-amnesic }\end{array}$ & $\begin{array}{l}\text { in vivo: } \\
\text { mice, rat }\end{array}$ & {$[37,39,40]$} \\
\hline Total alkaloidal extracts of MKL & $\begin{array}{l}\text { AChE inhibition } \\
\text { BACE1 inhibition } \\
\text { Antioxidant activity }\end{array}$ & $\begin{array}{l}\text { in vivo: } \\
\text { mice }\end{array}$ & [36] \\
\hline $\begin{array}{l}\text { Mahanimbine } \\
\text { from Murraya koenigii }\end{array}$ & $\begin{array}{c}\text { AChE inhibition } \\
\text { BACE1 inhibition } \\
\text { Antioxidant activity } \\
\text { Decreased ROS, MDA } \\
\text { Nrf2-dependent induction of antioxidant enzymes } \\
\text { Increased CAT, GRD, SOD, CAT } \\
\text { Decreased NF-kB, TNF- } \alpha, \text { IL-1 } \beta \\
\text { Decreased A } \beta \text { accumulation }\end{array}$ & $\begin{array}{l}\text { in vitro: } \\
\text { SK-N-SH cells, } \\
\text { in vivo: } \\
\text { mice }\end{array}$ & {$[39,44-49]$} \\
\hline Girinimbinefrom Murraya koenigii & $\begin{array}{c}\text { COX-2 inhibitor } \\
\text { Decreased NF- } \kappa \text { B, TNF- } \alpha \text {, IL-6, IL-1 } \beta \text {, iNOS } \\
\text { Decreased MDA } \\
\text { Increased GSH }\end{array}$ & $\begin{array}{l}\text { in silico, } \\
\text { in vitro: } \\
\text { MDA-MB-231 }\end{array}$ & {$[53,55]$} \\
\hline $\begin{array}{c}\text { Murrayanine } \\
\text { from Murraya koenigii }\end{array}$ & $\begin{array}{l}\text { Decreased iNOS and COX-2, PGE2, NO, I- } k \beta \\
\text { phosphorylation and NF- } \beta B\end{array}$ & $\begin{array}{c}\text { in vitro: } \\
\text { RAW } 264.7 \text { cells }\end{array}$ & {$[51,52]$} \\
\hline $\begin{array}{c}\text { Murrayanol } \\
\text { from Murraya koenigii }\end{array}$ & Anti-inflammatory & in vitro: & [39] \\
\hline $\begin{array}{l}\text { Murrayamine-E } \\
\text { from Murraya koenigii }\end{array}$ & Increased neurite outgrowth & $\begin{array}{l}\text { in vivo: } \\
\text { mice }\end{array}$ & [40] \\
\hline $\begin{array}{c}\text { Phyto-carbazole alkaloids from } \\
\text { Murraya tetramera and } \\
\text { Murraya kwangsiensis }\end{array}$ & Decreased NO & $\begin{array}{l}\text { in vitro: } \\
\text { BV-2 cells }\end{array}$ & {$[42,43]$} \\
\hline Clausena lansium peel extract & $\begin{array}{c}\text { Antioxidant activity } \\
\text { Increased survival of neurons } \\
\text { Decreased oxidative stress }\end{array}$ & $\begin{array}{l}\text { in vivo: } \\
\text { rat }\end{array}$ & {$[60]$} \\
\hline Prenylated carbazole alkaloids & Decreased NO & $\begin{array}{c}\text { in vitro: } \\
\text { RAW } 264.7 \text { cells }\end{array}$ & {$[56,57]$} \\
\hline $\begin{array}{l}\text { Clauemarazole E clausine } \mathrm{K} \text { and } \\
\text { clausine from the stems of } \\
\text { Clausena emarginata }\end{array}$ & Decreased NO & $\begin{array}{l}\text { in vitro: } \\
\text { BV-2 cells }\end{array}$ & [58] \\
\hline $\begin{array}{l}\text { Phyto-carbazoles from } \\
\text { Clausena dunniana }\end{array}$ & Decreased NO & $\begin{array}{l}\text { in vitro: } \\
\text { BV-2 cells }\end{array}$ & [59] \\
\hline $\begin{array}{l}\text { Hydroethanolic extract of the stems } \\
\text { and leaves of Clausena lenis }\end{array}$ & $\begin{array}{l}\text { Neuroprotection against } \\
\text { 6-OHDA induced apoptosis }\end{array}$ & $\begin{array}{l}\text { in vitro: } \\
\text { SH-SY5Y }\end{array}$ & [62] \\
\hline $\begin{array}{l}\text { Clausenalenine } \mathrm{A} \text { and its analogues } \\
\text { from Clausena lenis fruits }\end{array}$ & $\begin{array}{l}\text { Neuroprotection against } \\
\text { 6-OHDA induced apoptosis }\end{array}$ & $\begin{array}{l}\text { in vitro: } \\
\text { SH-SY5Y }\end{array}$ & {$[62]$} \\
\hline
\end{tabular}


Table 1. Cont.

\begin{tabular}{|c|c|c|c|}
\hline Plant/Carbazole Alkaloid & Mechanism of Neuroprotection & Study & Refs \\
\hline Clausine Z from Clausena excavata & CDK5 inhibitor & in vitro & [63] \\
\hline $\begin{array}{l}\text { O-Demethylmurrayanine, clausine } \\
\mathrm{D}, \text { carbazole-3-carboxylate from the } \\
\quad \text { roots of Clausena lansium }\end{array}$ & Decreased superoxide anion & in vitro & [57] \\
\hline $\begin{array}{l}\text { Geranylated phyto-carbazole } \\
\text { alkaloids (clauselansiumines A-B) } \\
\text { along with other carbazole } \\
\text { alkaloids from stem and leaves of } \\
\text { Clausena lansium }\end{array}$ & $\begin{array}{l}\text { Neuroprotection against } \\
\text { 6-OHDA induced apoptosis }\end{array}$ & $\begin{array}{l}\text { in vitro: } \\
\text { SH-SY5Y }\end{array}$ & {$[70,71]$} \\
\hline $\begin{array}{l}\text { Methanolic extract of } \\
\text { Glycosmis pentaphylla }\end{array}$ & $\begin{array}{l}\text { AChE inhibition } \\
\text { BChE inhibition } \\
\text { Antioxidant activity }\end{array}$ & in vitro & [85] \\
\hline $\begin{array}{l}\text { Total alkaloid extract of } \\
\text { Glycosmis pentaphylla }\end{array}$ & Antioxidant activity & in vitro & [86] \\
\hline $\begin{array}{l}\text { Zanthoaustrones A-C from the } \\
\text { roots of Zanthoxylum austrosinense }\end{array}$ & Decreased NO & in vitro & [95] \\
\hline $\begin{array}{l}\text { Zanthoxylum piperitum } \\
\text { Zanthoxylum schinifolium }\end{array}$ & $\begin{array}{c}\text { Antioxidant activity } \\
\text { Protect neuronal cells from high glucose-induced } \\
\text { cytotoxicity }\end{array}$ & in vitro & {$[98,101]$} \\
\hline $\begin{array}{l}\text { Methanolic and Ethyl acetate } \\
\text { extracts of Zanthoxylum } \\
\text { capense root }\end{array}$ & $\begin{array}{l}\text { Caspase-3 inhibition } \\
\text { Decreased ROS }\end{array}$ & $\begin{array}{l}\text { in vitro: } \\
\text { SH-SY5Y }\end{array}$ & [102] \\
\hline $\begin{array}{l}\text { Zanthoxylum bungeanum extracts } \\
\text { (water, volatile oil) }\end{array}$ & $\begin{array}{c}\text { Increased Nrf2, HO-1 } \\
\text { Increased PI3K/Akt, Bax } \\
\text { Reduced Bcl2 } \\
\text { Increased CAT, SOD, GSH } \\
\text { Decreased MDA } \\
\text { Antioxidant activity }\end{array}$ & $\begin{array}{l}\text { in vivo: } \\
\text { mice }\end{array}$ & [105] \\
\hline $\begin{array}{l}\text { Zanthoxylum fagara } \\
\text { Zanthoxylum rhoifolium } \\
\text { Zanthoxylum monophylla } \\
\text { Zanthoxylum quinduensis } \\
\text { Zanthoxylum davyi }\end{array}$ & AChE inhibition & in vitro & {$[113,114]$} \\
\hline $\begin{array}{l}\text { Hydroethanolic extract of } \\
\text { Zanthoxylum alatum }\end{array}$ & $\begin{array}{c}\text { AChE inhibition } \\
\text { TNF- } \alpha, \text { IL-1 } \beta \text { and IL-10 inhibition } \\
\text { Down-regulation of } N F \kappa B \text {, Tau, Bax, Caspase-3 } \\
\text { Up-regulation of Nrf2, HO-1, PP2A, BDNF }\end{array}$ & $\begin{array}{l}\text { in vivo: } \\
\text { rat }\end{array}$ & [115] \\
\hline
\end{tabular}

The present review discussed the neuroprotective potential of various phyto-carbazole alkaloids, exclusively present in the Rutaceae family plants, such as Murraya, Clausena, Glycosmis, Micromelum and Zanthoxylum. The discovery of the first naturally occurring phyto-carbazole alkaloid, murrayanine, from $M$. koenigii, is considered as a landmark in the progress of the chemistry and biology of carbazoles [31]. Phyto-carbazole alkaloids are important moieties in drug discovery and display a range of therapeutic activities, like anticancer, anti-tuberculosis, anti-HIV, antibacterial and neuroprotective. 


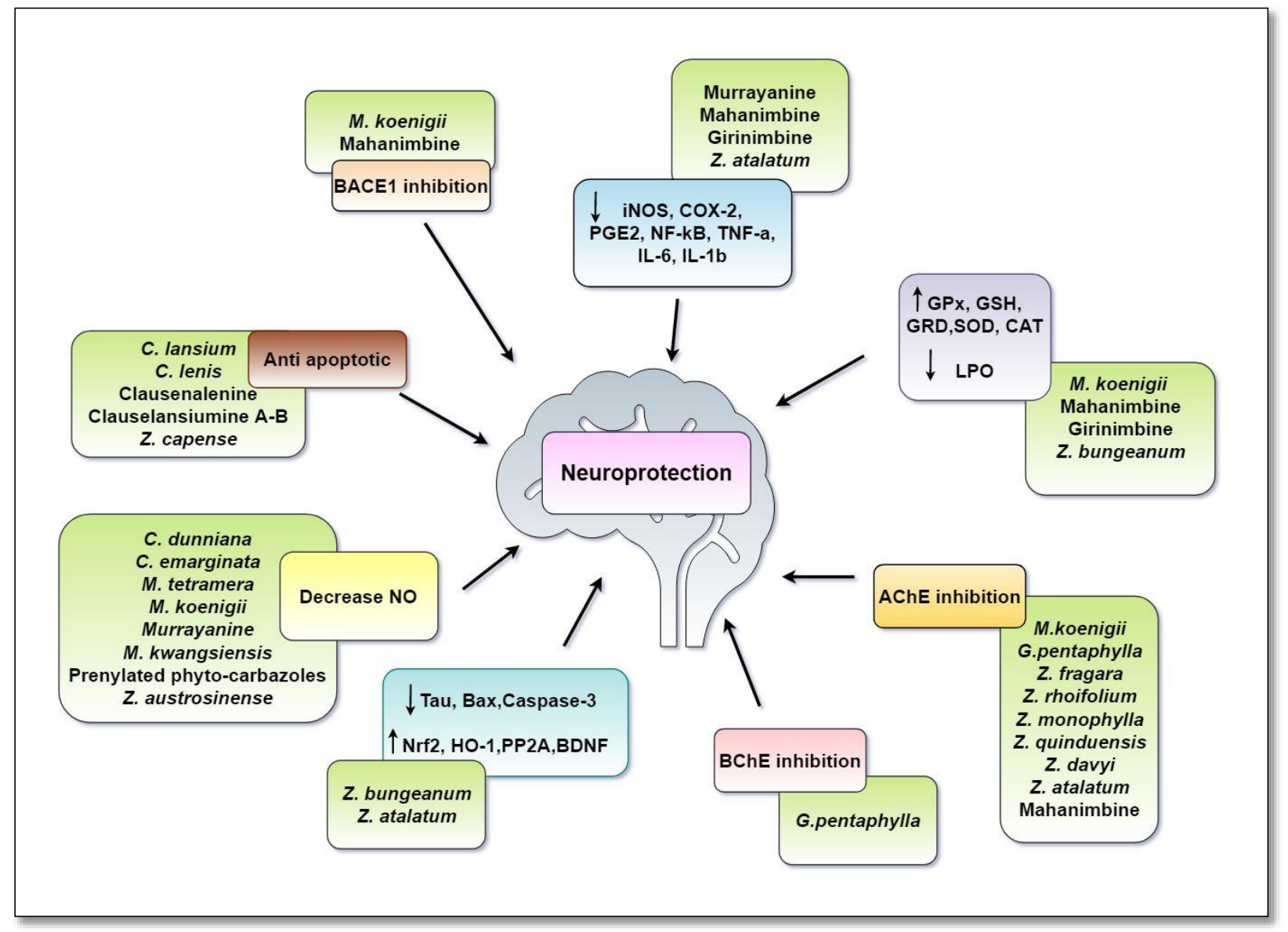

Figure 7. Multi-target mechanism displayed by Rutaceae family plant extracts and carbazole alkaloids in neurodegenerative diseases. Phyto extracts and carbazole alkaloids from Rutaceae family exerted a multi-target approach in ameliorating symptoms of AD. PP2A and BDNF activity/expression was decreased in $A D$, which stimulated the hyper-phosphorylation of Tau and APP, leading to overproduction of $A \beta$. Phyto-carbazoles prevented $A \beta$ aggregation by inhibiting cleavage of the APP by BACE-I, as well as by upregulating the expression of PP2A and BDNF. This caused a shift in the non-amyloidogenic pathway and reduced the levels of produced $A \beta$. A number of phyto-carbazoles were shown to reduce the levels of pro-inflammatory cytokines and inflammatory mediators (IL-6, IL-1 $\beta$, NF-k $\beta$, TNF- $\alpha$, iNOS, COX-2). Nrf2/HO-1 was an antioxidant signaling pathway, which was required for neuronal cell proliferation and survival. Down-regulation of this pathway was associated with various NDs. Phyto-carbazoles provided the neuroprotection by upregulating the expressions of the Nrf2/OH-1 pathway. They also reduced the oxidative stress by increasing the levels of antioxidant enzymes (SOD, CAT, GSH, GRD, GPx) and reducing lipid peroxidation (LPO). Caspase-3 and Bax were responsible for neuronal death and were up-regulated in AD. Phyto-carbazoles down-regulated their expressions and prevented apoptosis. ACh, a neurotransmitter essential for processing memory and learning, was decreased in both concentration and function in AD. Decreased levels of ACh could be restored by the $\mathrm{AChE}$ and $\mathrm{BChE}$ inhibitory activity of phyto-carbazole alkaloids. Overproduction of NO was linked to neuroinflammation, mitochondrial dysfunction and neurotoxicity in NDs. The increased levels of NO were also controlled by phyto-carbazole and plant extracts from the Rutaceae family. Abbreviations: A $\beta$ : Amyloid beta; ACh: Acetylcholine; APP: Amyloid Precursor Protein; AChE: Acetyl Cholinesterase Enzyme; BACE 1: Beta-Secretase 1; Bax: BCL2 Associated X; BChE: Butyl Cholinesterase Enzyme; BDNF: Brain-Derived Neurotrophic Factor; CAT: Catalase; COX2: Cycloxygenase-2; GSH: Reduced Glutathione; GRD: Glutathione Reductase; GPX: Glutathione Peroxidase; HO-1: Heme Oxygenase-1; iNOS: inducible Nitric Oxide Synthase; IL: Interleukin; NO: Nitric Oxide; NF-kß: Nuclear Factor Kappa B; Nrf2: Nuclear factor erythroid 2-Related Factor 2; PP2A: Protein Phosphatase 2A; SOD: Superoxide Dismutase; TNF- $\alpha$ : Tumor Necrosis factor- $\alpha$. 
In the past few decades, the therapeutic importance of natural and semi-synthetic carbazole alkaloids has expanded considerably. The phyto-carbazole alkaloids manifest the neuroprotection using a multi-target approach, lowering the oxidative stress, attenuating proinflammatory cytokines, inhibiting AChE and BACE-1, preventing/reducing $\mathrm{A} \beta$ protein aggregation and improving cognition. These pathophysiological features are common to almost all NDs. Unfortunately, the currently available FDA-approved drugs target only a single mechanism for the treatment of the complex pathophysiology of NDs. Hence, preparing a hybrid with carbazoles and FDA-approved drugs would expand their neuroprotective spectrum and would be a promising approach in drug discovery. The molecular mechanisms of action of most of the bioactive compounds are known within limitations. Henceforth, additional studies are necessary to fill this knowledge gap. Approaches based on the opportunities lying in untapped phyto-carbazole alkaloids (like murrayaine, girinimbine and mahanine) in the field of neuroprotection should also be explored. Other phyto-carbazole alkaloids that have revealed significant neuroprotective activity should be subjected to clinical trials to further assess their potential as a new drug or as pharmacophores for the development of a new generation of therapeutic agents.

To conclude, the phyto-carbazole alkaloids from the Rutaceae family were proven to be promising candidates in both the drug designing by natural sources and the development of nutraceuticals. We believe that the current review provides a colloquium of information that will help future investigation on the use of underutilized phyto-carbazole alkaloids to discover new neuroprotective drugs with the aid of animal models and clinical trials.

Author Contributions: Conceptualization, N.S. and S.S.A.A.; writing-original draft preparation, N.S.; writing — review and editing, N.S., M.A.T. and S.S.A.A.; funding acquisition, S.S.A.A. All authors have read and agreed to the published version of the manuscript.

Funding: This research was funded by the National Research Foundation of Korea and by the Korean Government (2020R1A2B5B01002463 and 2021R1A6A1A03038996).

Conflicts of Interest: The authors declare no conflict of interest.

\section{References}

1. Winner, B.; Kohl, Z.; Gage, F.H. Neurodegenerative disease and adult neurogenesis. Eur. J. Neurosci. 2011, 33, 1139-1151. [CrossRef]

2. Finkel, T. Signal transduction by reactive oxygen species. J. Cell Biol. 2011, 194, 7-15. [CrossRef]

3. Sharma, N.; Tan, M.A.; An, S.S.A. Mechanistic aspects of Apiaceae family spices in ameliorating Alzheimer's disease. Antioxidants 2021, 10, 1571. [CrossRef] [PubMed]

4. Murray, A.P.; Faraoni, M.B.; Castro, M.J.; Alza, N.P.; Cavallaro, V. Natural AChE inhibitors from plants and their contribution to Alzheimer's disease therapy. Curr. Neuropharmacol. 2013, 11, 388-413. [CrossRef] [PubMed]

5. Cui, X.; Lin, Q.; Liang, Y. Plant-derived antioxidants protect the nervous system from aging by inhibiting oxidative stress. Front. Aging Neurosci. 2020, 12, 209. [CrossRef]

6. Sharma, N.; Tan, M.A.; An, S.S.A. Phytosterols: Potential metabolic modulators in neurodegenerative diseases. Int. J. Mol. Sci. 2021, 22, 12255. [CrossRef] [PubMed]

7. Głuszyńska, A. Biological potential of carbazole derivatives. Eur. J. Med. Chem. 2015, 94, 405-426. [CrossRef]

8. Ito, C.; Itoigawa, M.; Aizawa, K.; Yoshida, K.; Ruangrungsi, N.; Furukawa, H. $\gamma$-Lactone carbazoles from Clausena anisata. J. Nat. Prod. 2009, 72, 1202-1204. [CrossRef]

9. Thiratmatrakul, S.; Yenjai, C.; Waiwut, P.; Vajragupta, O.; Reubroycharoen, P.; Tohda, M.; Boonyarat, C. Synthesis, biological evaluation and molecular modeling study of novel tacrine-carbazole hybrids as potential multifunctional agents for the treatment of Alzheimer's disease. Eur. J. Med. Chem. 2014, 75, 21-30. [CrossRef]

10. Börger, C.; Bruetting, C.; Julich-Gruner, K.K.; Hesse, R.; Kumar, V.P.; Kutz, S.K.; Ronnefahrt, M.; Thomas, C.; Wan, B.; Franzblau, S.G.; et al. Anti-tuberculosis activity and structure-activity relationships of oxygenated tricyclic carbazole alkaloids and synthetic derivatives. Bioorg. Med. Chem. 2017, 25, 6167-6174. [CrossRef]

11. Yang, J.-H.; Wang, X.-Y.; Zhou, Y.-P.; Lu, R.; Chen, C.-H.; Zhang, M.-H.; Cheng, Y.-Y.; Morris-Natschke, S.; Lee, K.-H.; Wang, Y.-S. Carbazole alkaloids from Clausena anisumolens: Isolation, characterization, and anti-HIV evaluation. Molecules 2020, 25, 99. [CrossRef] [PubMed]

12. Schmidt, A.W.; Reddy, K.R.; Knölker, H.J. Occurrence, biogenesis, and synthesis of biologically active carbazole alkaloids. Chem. Rev. 2012, 112, 3193-3328. [CrossRef] 
13. Greger, H. Phytocarbazoles: Alkaloids with great structural diversity and pronounced biological activities. Phytochem. Rev. 2017, 16, 1095-1153. [CrossRef]

14. Birari, R.; Roy, S.K.; Singh, A.; Bhutani, K.K. Pancreatic lipase inhibitory alkaloids of Murraya koenigii leaves. Nat. Prod. Commun. 2009, 4, 1089-1092. [CrossRef] [PubMed]

15. Birari, R.; Javia, V.; Bhutani, K.K. Antiobesity and lipid lowering effects of Murraya koenigii (L.) Spreng leaves extracts and mahanimbine on high fat diet induced obese rats. Fitoterapia 2010, 81, 1129-1133. [CrossRef] [PubMed]

16. Ito, C.; Itoigawa, M.; Nakao, K.; Murata, T.; Kaneda, N.; Furukawa, H. Apoptosis of HL-60 leukemia cells induced by carbazole alkaloids isolated from Murraya euchrestifolia. J. Nat. Med. 2012, 66, 357-361. [CrossRef]

17. Huang, L.; Feng, Z.-L.; Wang, Y.-T.; Lin, L.-G. Anticancer carbazole alkaloids and coumarins from Clausena plants: A review. Chin. J. Nat. Med. 2017, 15, 881-888. [CrossRef]

18. Guillonneau, C.; Pierré, A.; Charton, Y.; Guilbaud, N.; Kraus-Berthier, L.; Léonce, S.; Michel, A.; Bisagni, E.; Atassi, G. Synthesis of 9-O-substituted derivatives of 9-hydroxy-5, 6-dimethyl-6 H-pyrido [4, 3-b] carbazole-1-carboxylic acid (2-(Dimethylamino) ethyl) amide and their 10-and 11-methyl analogues with improved antitumor activity. J. Med. Chem. 1999, 42, 2191-2203. [CrossRef]

19. Chen, Y.; Cao, N.; Lv, H.; Zeng, K.; Yuan, J.; Guo, X.; Zhao, M.; Tu, P.; Jiang, Y. Antiinflammatory and cytotoxic carbazole alkaloids from Murraya kwangsiensis. Phytochemistry 2020, 170, 112186. [CrossRef]

20. Zhang, F.F.; Gan, L.L.; Zhou, G.H. Synthesis, anti-bacterial and antifungal activities of some carbazole derivatives. Bioorg. Med. Chem. 2010, 20, 1881-1884. [CrossRef]

21. Thevissen, K.; Marchand, A.; Chaltin, P.; Meert, E.M.K.; Cammue, B.P.A. Antifungal carbazoles. Curr. Med. Chem. 2009, 16, 2205-2211. [CrossRef] [PubMed]

22. Patel, O.P.; Mishra, A.; Maurya, R.; Saini, D.; Pandey, J.; Taneja, I.; Raju, K.S.R.; Kanojiva, S.; Shukla, S.K.; Srivastava, M.N.; et al. Naturally occurring carbazole alkaloids from Murraya koenigii as potential antidiabetic agents. J. Nat. Prod. 2016, 79, 1276-1284. [CrossRef]

23. Wei, R.; Ma, Q.; Li, T.; Liu, W.; Sang, Z.; Li, M.; Liu, S. Carbazole alkaloids with antiangiogenic activities from Clausena sanki. Bioorg. Chem. 2018, 77, 387-392. [CrossRef] [PubMed]

24. Ashok, P.; Chander, S.; Smith, T.K.; Sankaranarayanan, M. Design, synthesis and biological evaluation of piperazinyl- $\beta$-carboline derivatives as anti-leishmanial agents. Eur. J. Med. Chem. 2018, 150, 559-566. [CrossRef] [PubMed]

25. Zang, Y.; Liu, K.; Wang, W.; Li, C.; Ma, J.; Yang, J.; Chen, X.; Wang, X.; Zhang, D. Claulansine F-donepezil hybrids as antiAlzheimer's disease agents with cholinergic, free-radical scavenging, and neuroprotective activities. Molecules 2021, $26,1303$. [CrossRef] [PubMed]

26. Kongkathip, B.; Kongkathip, N.; Sunthitikawinsakul, A.; Napaswat, C.; Yoosook, C. Anti-HIV-1 constituents from Clausena excavata: Part II. Carbazoles and a pyranocoumarin. Phytother. Res. 2005, 19, 728-731. [CrossRef]

27. Saengkhae, C.; Salerno, M.; Ades, D.; Siove, A.; le Moyec, L.; Migonney, V.; Garnier-Suillerot, A. Ability of carbazole salts, inhibitors of Alzheimer beta-amyloid fibril formation, to cross cellular membranes. Eur. J. Med. Chem. 2007, 559, 124-131.

28. Bertini, S.; Asso, V.; Ghilardi, E.; Granchi, C.; Manera, C.; Minutolo, F.; Saccomanni, G.; Bortolato, A.; Mason, J.; Moro, S.; et al. Carbazole-containing arylcarboxamides as bace1 inhibitors. Bioorg. Med. Chem. Lett. 2011, 21, 6657-6661. [CrossRef]

29. Fang, L.; Fang, X.; Gou, S.; Lupp, A.; Lenhardt, I.; Sun, Y.; Huang, Z.; Chen, Y.; Zhang, Y.; Fleck, C. Design, synthesis and biological evaluation of D-ring opened galantamine analogs as multifunctional anti-Alzheimer agents. Eur. J. Med. Chem. 2014, 76, 376-386. [CrossRef]

30. Zhu, D.; Chen, M.; Li, M.; Luo, B.; Zhao, Y.; Huang, P.; Xue, F.; Rapposelli, S.; Pi, R.; Wen, S. Discovery of novel N-substituted carbazoles as neuroprotective agents with potent anti-oxidative activity. Eur. J. Med. Chem. 2013, 68, 81-88. [CrossRef]

31. Knoelker, H.J.; Reddy, K.R. Chapter 3-Biogenesis of carbazole alkaloids. In The Alkaloids: Chemistry and Biology; Cordell, G.A., Ed.; Academic Press: Leiden-Boston, The Netherlands, 2008; Volume 65, pp. 159-180.

32. Meena, S.; Kumar, S.R.; Dwivedi, V.; Singh, A.K.; Chanotiya, C.S.; Akhtar, M.Q.; Kumar, K.; Shasany, A.K.; Nagegowda, D.A. Transcriptomic insight into terpenoid and carbazole alkaloid biosynthesis, and functional characterization of two terpene synthases in curry tree (Murraya koenigii). Sci. Rep. 2017, 7, 44126. [CrossRef] [PubMed]

33. Iyer, D.; Devi, U. Phyto-pharmacology of Murraya koenigii (L.). Pharmacog. Rev. 2008, 2, 180-184.

34. Balakrishnan, R.; Vijayraja, D.; Jo, S.H.; Ganesan, P.; In, S.K.; Choi, D.K. Medicinal profile, phytochemistry, and pharmacological activities of Murraya koenigii and its primary bioactive compounds. Antioxidants 2020, 9, 101. [CrossRef] [PubMed]

35. Mani, V.; Ramasamy, K.; Ahmad, A.; Wahab, S.N.; Jaafar, S.M.; Kek, T.L.; Salleh, M.Z.; Majeed, A.B.A. Effects of the total alkaloidal extract of Murraya koenigii leaf on oxidative stress and cholinergic transmission in aged mice. Phytother. Res. 2013, 27, 46-53. [CrossRef] [PubMed]

36. Tachibana, Y.; Kikuzaki, H.; Lajis, N.H.; Nakatani, N. Antioxidative activity of carbazoles from Murraya koenigii leaves. J. Agr. Food Chem. 2001, 49, 5589-5594. [CrossRef]

37. Vasudevan, M.; Parle, M. Antiamnesic potential of Murraya koenigii leaves. Phytother. Res. 2009, 23, 308-316. [CrossRef]

38. Nalli, Y.; Khajuria, V.; Gupta, S.; Arora, P.; Riyaz-Ul-Hassan, S.; Ahmed, Z.; Ali, A. Four new carbazole alkaloids from Murraya koenigii that display anti-inflammatory and anti-microbial activities. Org. Biomol. Chem. 2016, 14, 3322-3332. [CrossRef]

39. Ramsewak, R.S.; Nair, M.G.; Strasburg, G.M.; DeWitt, D.L.; Nitiss, J.L. Biologically active carbazole alkaloids from Murraya koenigii. J. Agric. Food Chem. 1999, 47, 444-447. [CrossRef] 
40. Yano, M.; Nakashima, S.; Kasa, S.; Nakamura, S.; Nishimura, K.; Oda, Y.; Takata, K.; Matsuda, H. Accelerative effects of carbazole-type alkaloids from Murraya koenigii on neurite outgrowth and their derivative's in vivo study for spatial memory. J. Nat. Med. 2020, 74, 448-455. [CrossRef]

41. Ma, X.; Chen, H.; Zhu, S.; Tu, P.; Jiang, Y. Trimeric and dimeric carbazole alkaloids from Murraya microphylla. Molecules 2021, 26, 5689. [CrossRef]

42. Lv, H.; Wen, R.; Zhou, Y.; Zeng, K.; Li, J.; Guo, X.; Tu, P.; Jiang, Y. Nitrogen oxide inhibitory trimeric and dimeric carbazole alkaloids from Murraya tetramera. J. Nat. Prod. 2015, 78, 2432-2439. [CrossRef] [PubMed]

43. Lyu, H.-N.; Zhou, Y.; Wen, R.; Tu, P.-F.; Jiang, Y. Nitric oxide inhibitory carbazole alkaloids from the folk medicine Murraya tetramera C.C. Huang. Chem. Biodivers. 2020, 17, e2000490. [CrossRef] [PubMed]

44. Kumar, N.S.; Mukherjee, P.K.; Bhadra, S.; Saha, B.P.; Pal, B.C. Acetylcholinesterase inhibitory potential of a carbazole alkaloid, mahanimbine, from Murraya koenigii. Phytother. Res. 2010, 24, 629-631. [CrossRef] [PubMed]

45. Azahan, N.S.M.; Mani, V.; Ramasamy, K.; Lim, S.M.; Alhowail, A.; Sajid, S.; Majeed, A.B.A. Neuroprotective potential of mahanimbine against lipopolysaccharides (LPS)-induced neuronal deficits on SK-N-SH cells and antioxidant potentials in ICR mice brain. J. Pharm. Res. Int. 2019, 31, 1-11. [CrossRef]

46. Azahan, N.S.M.; Mani, V.; Ramasamy, K.; Lim, S.M.; James, R.M.J.; Alsharidah, M.; Alhowail, A.; Majeed, A.B.A Mahanimbine-induced neuroprotection via cholinergic system and attenuated amyloidogenesis as well as neuroinflammation in lipopolysaccharides-induced mice. Pharmacog. Mag. 2020, 16, 57-63.

47. Fakhri, S.; Pesce, M.; Patruno, A.; Moradi, S.Z.; Iranpanah, A.; Farzaei, M.H.; Sobarzo-Sánchez, E. Attenuation of Nrf2/Keap1/ARE in Alzheimer's disease by plant secondary metabolites: A mechanistic review. Molecules 2020, 25, 4926. [CrossRef]

48. Liang, S.; Zheng, Y.; Lei, L.; Deng, X.; Ai, J.; Li, Y.; Zhang, T.; Mei, Z.; Ren, Y. Corydalis edulis total alkaloids (CETA) ameliorates cognitive dysfunction in rat model of Alzheimer disease through regulation of the antioxidant stress and MAP2/NF- $\kappa$ B. $J$. Ethnopharmacol. 2020, 251, 112540. [CrossRef]

49. Mani, V.; Ramasamy, K.; Ahmad, A.; Parle, M.; Shah, S.A.A.; Majeed, A.B.A. Protective effects of total alkaloidal extract from Murraya koenigii leaves on experimentally induced dementia. Food Chem. Toxicol. 2012, 50, 1036-1044. [CrossRef]

50. Chakraborty, D.P.; Barman, B.K.; Bose, P.K. On the constitution of murrayanine, a carbazole derivative isolated from Murraya koengii Spreng. Tetrahedron 1965, 21, 681-685. [CrossRef]

51. Laroux, F.S.; Lefer, D.J.; Kawachi, S.; Scalia, R.; Cockrell, A.S.; Gray, L.; Van der Heyde, H.; Hoffman, J.M.; Grisham, M.B. Role of nitric oxide in the regulation of acute and chronic inflammation. Antioxid. Redox Signal. 2000, 2, 391-396. [CrossRef]

52. Jha, N.K.; Jha, S.K.; Kar, R.; Nand, P.; Swati, K.; Goswami, V.K. Nuclear factor-kappa $\beta$ as a therapeutic target for Alzheimer's disease. J. Neurochem. 2019, 150, 113-137. [CrossRef] [PubMed]

53. Pandya, P.N.; Kumar, S.P.; Bhadresha, K.; Patel, C.N.; Patel, S.K.; Rawal, R.M.; Mankad, A.U. Identification of promising compounds from curry tree with cyclooxygenase inhibitory potential using a combination of machine learning, molecular docking, dynamics simulations and binding free energy calculations. Mol. Simul. 2020, 46, 812-822. [CrossRef]

54. Iman, V.; Mohan, S.; Abdelwahab, S.I.; Karimian, H.; Nordin, N.; Fadaeinasab, M.; Noordin, M.H.; Noor, S.M. Anticancer and anti-inflammatory activities of girinimbine isolated from Murraya koenigii. Drug. Des. Devel. Ther. 2017, 11, 103-121. [CrossRef] [PubMed]

55. Mohan, S.; Hobani, Y.H.; Shaheen, E.; Abou-Elhamd, A.S.; Alhazmi, H.A.; Abdelwahab, S.I. Girinimbine from curry leaves promotes gastro protection against ethanol induced peptic ulcers and improves healing via regulation of anti-inflammatory and antioxidant mechanisms. Food Funct. 2020, 11, 3493-3505. [CrossRef]

56. Liu, Y.-P.; Guo, J.-M.; Xie, Z.; Suo, X.-Y.; Liu, Z.-Y.; Qiao, Z.-H.; Guan, R.-Q.; Bian, Y.; Qiang, L.; Fu, Y.-H. Clausanisumine, a prenylated bicarbazole alkaloid from the fruits of Clausena anisumolens and its potential anti-HIV activity. J. Org. Chem. 2021, 86, 17722-17726. [CrossRef]

57. Liu, Y.-P.; Hu, S.; Liu, Y.-Y.; Zhang, M.-M.; Zhang, W.-H.; Qiang, L.; Fu, Y.H. Anti-inflammatory and antiproliferative prenylated carbazole alkaloids from Clausena vestita. Bioorg. Chem. 2019, 91, 103107. [CrossRef]

58. Liu, Y.-P.; Guo, J.-M.; Wang, X.-P.; Liu, Y.-Y.; Zhang, W.; Wang, T.; Qiang, L.; Fu, Y. Geranylated carbazole alkaloids with potential neuroprotective activities from the stems and leaves of Clausena lansium. Bioorg. Chem. 2019, 92, 103278. [CrossRef]

59. Xia, H.-M.; Yang, G.-Q.; Li, C.-J.; Yang, J.-Z.; Ma, J.; Zhang, D.; Li, Y.; Li, L.; Zhang, D.-M. Clauemarazoles A-G, seven carbazole alkaloids from the stems of Clausena emarginata. Fitoterapia 2015, 103, 83-89. [CrossRef]

60. Cao, N.; Chen, Y.; Ma, X.; Zeng, K.; Zhao, M.; Tu, P.; Li, J.; Jiang, Y. Bioactive carbazole and quinoline alkaloids from Clausena dunniana. Phytochem. 2018, 151, 1-8. [CrossRef]

61. Phachonpai, W.; Tongun, T. Neuroprotective and cognitive enhancing effects of Clausena lansium (Lour.) skeels peels extract in ischemic rat brains. J. Applied Pharm. Sci. 2021, 11, 001-008.

62. Yan, G.; Li, Y.-J.; Zhao, Y.-Y.; Guo, J.-M.; Zhang, W.-H.; Zhang, M.-M.; Fu, Y.-H.; Liu, Y.-P. Neuroprotective carbazole alkaloids from the stems and leaves of Clausena lenis. Nat. Prod. Res. 2021, 35, 2002-2009. [CrossRef] [PubMed]

63. Potterat, O.; Puder, C.; Bolek, W.; Wagner, K.; Ke, C.; Ye, Y.; Gillardon, F. Clausine Z, a new carbazole alkaloid from Clausena excavata with inhibitory activity on CDK5. Pharmazie 2005, 60, 637-639. [CrossRef] [PubMed] 
64. Weishaupt, J.H.; Kussmaul, L.; Grotsch, P.; Heckel, A.; Rohde, G.; Romig, H.; Bahr, M.; Gillardon, F. Inhibition of CDK5 is protective in necrotic and apoptotic paradigms of neuronal cell death and prevents mitochondrial dysfunction. Mol. Cell. Neurosci. 2003, 24, 489-502. [CrossRef]

65. Pao, P.-C.; Tsai, L.H. Three decades of Cdk5. J. Biomed. Sci. 2021, 28, 79. [CrossRef]

66. Tseng, H.-C.; Zhou, Y.-Z.; Shen, Y.; Tsai, L.-H. A survey of Cdk5 activator p35 and p25 levels in Alzheimer's disease brains. FEBS Lett. 2002, 523, 58-62. [CrossRef]

67. Lee, M.S.; Kwon, Y.T.; Li, M.; Peng, J.; Friedlander, R.M.; Tsai, L.H. Neurotoxicity induces cleavage of p35 to p25 by calpain Nature 2000, 405, 360-364. [CrossRef]

68. Patrick, G.N.; Zukerberg, L.; Nikolic, M.; de la Monte, S.; Dikkes, P.; Tsai, L.-H. Conversion of p35 to p25 deregulates Cdk5 activity and promotes neurodegeneration. Nature 1999, 402, 615-622. [CrossRef]

69. Shelton, S.B.; Johnson, G.V. Cyclin-dependent kinase-5 in neurodegeneration. J. Neurochem 2004, 88, 1313-1326. [CrossRef]

70. Liu, Y.-P.; Guo, J.-M.; Liu, Y.-Y.; Hu, S.; Yan, G.; Qiang, L.; Fu, Y.-H. Carbazole alkaloids with potential neuroprotective activities from the fruits of Clausena lansium. J. Agric. Food Chem. 2019, 67, 5764-5771. [CrossRef]

71. Sun, X.; Li, C.; Ma, J.; Zang, Y.; Huang, J.; Chen, N.; Wang, X.; Zhang, D. New amide alkaloids and carbazole alkaloid from the stems of Clausena lansium. Fitoterapia 2021, 154, 104999. [CrossRef]

72. Liu, H.; Li, C.-J.; Yang, J.-Z.; Ning, N.; Si, Y.-K.; Li, L.; Chen, N.-H.; Zhao, J.; Zhang, D.-M. Carbazole alkaloids from the stems of Clausena lansium. J. Nat. Prod. 2012, 75, 677-682. [CrossRef] [PubMed]

73. Liu, D.-D.; Yuan, X.; Chu, S.-F.; Chen, C.; Ren, Q.; Luo, P.; Lin, M.-Y.; Wang, S.S.; Zhu, T.B.; Ai, Q.D.; et al. CZ-7, a new derivative of Claulansine $\mathrm{F}$, ameliorates 2VO-induced vascular dementia in rats through a Nrf2-mediated antioxidant responses. Acta Pharmacol. Sin. 2019, 40, 425-440. [CrossRef] [PubMed]

74. Li, J.-W.; Ning, N.; Ma, Y.-Z.; Zhang, R.; Tan, F.; Chen, N.-H. Claulansine F suppresses apoptosis induced by sodium nitroprusside in PC12 cells. Free Radic. Res. 2013, 47, 488-497. [CrossRef] [PubMed]

75. Zang, Y.; Song, X.; Li, C.; Ma, J.; Chu, S.; Liu, D.; Ren, Q.; Li, Y.; Chen, N.; Zhang, D. Pyrano[3,2-a]carbazole alkaloids as effective agents against ischemic stroke in vitro and in vivo. Eur. J. Med. Chem. 2018, 143, 438-448. [CrossRef]

76. Sivakumar, M.; Chamundeeswari, D. Identification of active phytocomponents in the ethyl acetate extract of Glycosmis pentaphylla (Retz.) DC. by using GC-MS. Int. J. Med. Health Biomed. Bioeng. Pharm. Eng. 2016, 10, 453-457.

77. Murugan, N.; Natarajan, D. Phytochemical, antioxidant and antibacterial activities of Glycosmis pentaphylla (Rutaceae) leaf extracts against selected multi-drug resistant bacteria. J. Chem. Pharm. Res. 2016, 8, 737-744.

78. Chowdhury, M.; Sultana, I.; Tasneem, Z.; Jubair, A.A. Phytochemical and pharmacological screening of Glycosmis pentaphylla (Retz.) DC. (fam. Rutaceae). Int. J. Sci. Eng. Res. 2015, 6, 928-934.

79. Raju, N.J.; Rao, B.G. Evaluation of hepatoprotective activity of Glycosmis pentaphylla roots against CCl4-induced acute liver injury in rats. Int. J. Pharm. Sci. Rev. Res. 2010, 4, 81-86.

80. Bhattacharyya, P.; Chowdhury, B.K. Glycozolidal, a new carbazole alkaloid from Glycosmis pentaphylla. J. Nat. Prod. 1985, 48, 465-466. [CrossRef]

81. Bhattacharyya, P.; Chakrabartty, P.K.; Chowdhury, B.K. Glycozolidol, an antibacterial carbazole alkaloid from Glycosmis pentaphylla. Phytochemistry 1985, 24, 882-883. [CrossRef]

82. Chakraborty, A.; Chowdhury, B.K.; Jash, S.S.; Biswas, G.K.; Bhattacharyya, S.K.; Bhattacharyya, P. Carbazole alkaloids from Glycosmis pentaphylla. Phytochemistry 1992, 31, 2503-2505. [CrossRef]

83. Chen, Y.; Tang, C.; Wu, Y.; Mo, S.; Wang, S.; Yang, G.; Mei, Z. Glycosmisines A and B: Isolation of two new carbazole-indole-type dimeric alkaloids from Glycosmis pentaphylla and an evaluation of their antiproliferative activities. Org. Biomol. Chem. 2015, 13, 6773-6781. [CrossRef]

84. Yang, G.-Z.; Wu, Y.; Chen, Y. Alkaloids from the stems of Glycosmis pentaphylla. Helv. Chim. Acta 2012, 95, 1449-1454. [CrossRef]

85. Rahman, R.; Islam, T.; Faruquee, H.M.; Akhter, S.; Haque, M.A. Evaluation of antioxidant, cholinesterase inhibitory properties, and antibacterial potentials of Glycomis pentaphylla leaf extract relevant to the treatment of Alzheimer's disease. J. Appl. Pharm. 2017, 9, 17-30. [CrossRef]

86. Prakasia, P.P.; Nair, A.S. Evaluation of in vitro antioxidant potential of the total crude alkaloid extract of Glycosmis pentaphylla (Retz.) Correa leaves. Int. J. Pharm. Pharm. Sci. 2016, 8, 85-91.

87. Ma, C.; Case, R.J.; Wang, Y.; Zhang, H.-J.; Tan, G.T.; Van Hung, N.; Cuong, N.M.; Franzblau, S.G.; Soejarto, D.D.; Fong, H.H.S.; et al. Anti-tuberculosis constituents from the stem bark of Micromelum hirsutum. Planta Med. 2005, 71, 261-267. [CrossRef]

88. Siridechakorn, I.; Ritthiwigrom, T.; Laphookhieo, S. Coumarins and carbazole alkaloids from the roots of Micromilum glanduliferum. Biochem. Syst. Ecol. 2012, 40, 69-70. [CrossRef]

89. Bowen, I.H.; Perera, K. Alkaloids, coumarins and flavonoids of Micromelum zeylanicum. Phytochemistry 1982, 21, $433-437$. [CrossRef]

90. Nakahara, K.; Trakoontivakorn, G.; Alzoreky, N.S.; Ono, H.; Onishi-Kameyama, M.; Yoshida, M. Antimutagenicity of some edible Thai plants, and a bioactive carbazole alkaloid, mahanine, isolated from Micromelum minutum. J. Agric. Food Chem. 2002, 50, 4796-4802. [CrossRef]

91. Roy, M.K.; Thalang, V.N.; Trakoontivakorn, G.; Nakahara, K. Mechanism of mahanine-induced apoptosis in human leukemia cells (HL-60). Biochem. Pharmacol. 2004, 67, 41-51. [CrossRef] 
92. Yang, X.-L.; Xie, Z.-H.; Jiang, X.-J.; Huang, Y.-B.; Liu, J.-K. A new acridone alkaloid from Micromelum integerrimum. Chem. Pharm. Bull. 2009, 57, 734-735. [CrossRef] [PubMed]

93. Thant, T.M.; Aminah, N.S.; Kristanti, A.N.; Ramadhan, R.; Aung, H.T.; Takaya, Y. Phytoconstituents of Genus Micromelum and their bioactivity-A Review. Nat. Prod. Commun. 2020, 15, 1-15. [CrossRef]

94. Okagu, I.U.; Ndefo, J.C.; Aham, E.C.; Udenigwe, C.C. Zanthoxylum Species: A comprehensive review of traditional uses, phytochemistry, pharmacological and nutraceutical applications. Molecules 2021, 26, 4023. [CrossRef]

95. Fu, Y.-H.; Guo, J.-M.; Xie, Y.-T.; Hua, J.; Dai, Y.-Y.; Zhang, W.; Lin, T.C.; Liu, Y.-P. Structural characterization, antiproliferative and anti-inflammatory activities of alkaloids from the roots of Zanthoxylum austrosinense. Bioorg. Chem. 2020, 102, 104101. [CrossRef]

96. Samad, A.; Badshah, S.; Khan, D.; Ali, F.; Amanullah, M.; Hanrahan, J. New prenylated carbazole alkaloids from Zanthoxylum armatum. J. Asian Nat. Prod. Res. 2014, 16, 1126-1131. [CrossRef]

97. Macías, V.; Coy, E.; Cuca, L.E. Novel furocarbazole a lkaloids and antibacterial activity of ethanol extract from Zanthoxylum fagara (L.) Sargent. Rev. Colomb. Quim. 2010, 39, 333-341.

98. Han, H.J.; Park, S.K.; Kim, M.J.; An, J.W.; Lee, S.J.; Kang, J.Y.; Kim, J.M.; Heo, H.J. Industrial potential of domestic Zanthoxylum piperitum and Zanthoxylum schinifolium: Protective effect of both extracts on high glucose-induced neurotoxicity. Korean J. Food Sci. Technol. 2020, 52, 274-283.

99. Hsu, Y.-H.; Chen, Y.-W.; Wu, M.-H.; Tu, L.-H. Protein glycation by glyoxal promotes amyloid formation by islet amyloid polypeptide. Biophys. J. 2019, 116, 2304-2313. [CrossRef]

100. Kim, J.G.; Lim, J.J.; You, J.S.; Kwon, H.J.; Lim, H.B. Comparative study of bioactivity and safety evaluation of ethanolic extracts of Zanthoxylum schinifolium fruit and pericarp. Molecules 2021, 26, 5919. [CrossRef]

101. Seoposengwe, K.; Van Tonder, J.J.; Steenkamp, V. In vitro neuroprotective potential of four medicinal plants against rotenoneinduced toxicity in SH-SY5Y neuroblastoma cells. BMC Complement. Altern. Med. 2013, 13, 353. [CrossRef]

102. Menozzi-Smarrito, C.; Riera, C.E.; Munari, C.; Le Coutre, J.; Robert, F. Synthesis and evaluation of new alkylamides derived from $\alpha$-hydroxysanshool, the pungent molecule in Szechuan pepper. J. Agric. Food Chem. 2009, 57, 1982-1989. [CrossRef] [PubMed]

103. Deng, S.; Rong, H.; Tu, H.; Zheng, B.; Mu, X.; Zhu, L.; Zhou, X.; Peng, W.; Xu, M.; Zhang, E.; et al. Molecular basis of neurophysiological and antioxidant roles of Szechuan pepper. Biomed. Pharmacother. 2019, 112, 108696. [CrossRef] [PubMed]

104. Zhao, M.; Tang, X.; Gong, D.; Xia, P.; Wang, F.; Xu, S. Bungeanum improves cognitive dysfunction and neurological deficits in D-galactose-induced aging mice via activating PI3K/Akt/Nrf2 signaling pathway. Front. Pharmacol. 2020, 11, 71. [CrossRef]

105. Kerr, F.; Sofola-Adesakin, O.; Ivanov, D.K.; Gatliff, J.; Perez-Nievas, B.G.; Bertrand, H.C.; Martinez, P.; Callard, R.; Snoeren, I.; Cocheme, H.M.; et al. Direct Keap1-Nrf2 disruption as a potential therapeutic target for Alzheimer's disease. PLoS Genet. 2017, 13, e1006593. [CrossRef]

106. Matsuda, S.; Ikeda, Y.; Murakami, M.; Nakagawa, Y.; Tsuji, A.; Kitagishi, Y. Roles of PI3K/AKT/GSK3 pathway involved in psychiatric illnesses. Diseases 2019, 7, 22. [CrossRef]

107. Zeng, K.-W.; Wang, X.-M.; Ko, H.; Kwon, H.C.; Cha, J.W.; Yang, H.O. Hyperoside protects primary rat cortical neurons from neurotoxicity induced by amyloid $\beta$-protein via the PI3K/Akt/Bad/Bcl $\mathrm{XL}$-regulated mitochondrial apoptotic pathway. Eur. $J$. Pharmacol. 2011, 672, 45-55. [CrossRef]

108. Long, H.-Z.; Cheng, Y.; Zhou, Z.-W.; Luo, H.-Y.; Wen, D.-D.; Gao, L.-C. PI3K/AKT Signal Pathway: A Target of Natural Products in the Prevention and Treatment of Alzheimer's Disease and Parkinson's Disease. Front. Pharmacol. 2021, 12, 619. [CrossRef] [PubMed]

109. Wang, R.; Yang, S.; Nie, T.; Zhu, G.; Feng, D.; Yang, Q. Transcription factors: Potential cell death markers in Parkinson's disease Neurosci. Bull. 2017, 33, 552-560. [CrossRef]

110. Zhong, K.; Li, X.-J.; Gou, A.-N.; Huang, Y.-N.; Bu, Q.; Gao, H. Antioxidant and cytoprotective activities of flavonoid glycosides-rich extract from the leaves of Zanthoxylum bungeanum. J. Food Nutr. Res. 2014, 2, 349-356. [CrossRef]

111. Jeong, C.H.; Kwak, J.H.; Kim, J.H.; Choi, G.N.; Kim, D.O.; Heo, H.J. Neuronal cell protective and antioxidant effects of phenolics obtained from Zanthoxylum piperitum leaf using in vitro model system. Food Chem. 2011, 125, 417-422. [CrossRef]

112. Plazas, E.A.; Avila, M.C.; Delgado, W.A.; Patino, O.J.; Cuca, L.E. In vitro antioxidant and anticholinesterase activities of Colombian plants as potential neuroprotective agents. Res. J. Med. Plants 2018, 12,9-18. [CrossRef]

113. Adewusi, E.A.; Steenkamp, V. In vitro screening for acetylcholinesterase inhibition and antioxidant activity of medicinal plants from southern Africa. Asian Pac. J. Trop. Med. 2011, 4, 829-835. [CrossRef]

114. Saikia, B.; Barua, C.C.; Sarma, J.; Haloi, P.; Tamuli, S.M.; Kalita, D.J.; Purkayastha, A.; Barua, A.G. Zanthoxylum alatum ameliorates scopolamine-induced amnesia in rats: Behavioral, biochemical, and molecular evidence. Indian J. Pharmacol. 2018, 50, 30-38. [CrossRef] [PubMed]

115. Levinthal, D.J.; DeFranco, D.B. Reversible oxidation of ERK-directed protein phosphatases drives oxidative toxicity in neurons. $J$. Biol. Chem. 2005, 280, 5875-5883. [CrossRef] [PubMed]

116. Slutsky, I.; Abumaria, N.; Wu, L.-J.; Huang, C.; Zhang, L.; Li, B.; Zhao, X.; Govindarajan, A.; Zhao, M.-G.; Zhuo, M.; et al. Enhancement of learning and memory by elevating brain magnesium. Neuron 2010, 65, 165-177. [CrossRef]

117. Colucci-D' Amato, L.; Speranza, L.; Volpicelli, F. Neurotrophic factor BDNF, Physiological functions and therapeutic potential in depression, neurodegeneration and brain cancer. Int. J. Mol. Sci. 2020, 21, 7777. [CrossRef] 